Malone, K. M., E. B. Webb, D. Mengel, L. J. Kearns, S. W. Matteson, and A. E. McKellar. 2021. Secretive marsh bird habitat associations in the Mississippi Flyway: a meta-analysis. Avian Conservation and Ecology 16(2):12. https://doi.org/10.5751/ACE-01924-160212

Copyright (C) 2021 by the author(s). Published here under license by the Resilience Alliance.

Research Paper

\title{
Secretive marsh bird habitat associations in the Mississippi Flyway: a meta-analysis
}

\author{
Kristen M. Malone ${ }^{1}$ (D), Elisabeth B. Webb ${ }^{1,2}$, Doreen Mengel ${ }^{3}$, Laura J. Kearns ${ }^{4}$, Sumner W. Matteson ${ }^{5}$ and Ann E. McKellar $^{6}$ \\ ${ }^{1}$ University of Missouri, School of Natural Resources, Columbia, MO, ${ }^{2}$ U.S. Geological Survey, Missouri Cooperative Fish and \\ Wildlife Research Unit, ${ }^{3}$ Missouri Department of Conservation, Columbia, MO, ${ }^{4}$ Ohio Department of Natural Resources - \\ Division of Wildlife, Columbus, $\mathrm{OH},{ }^{5}$ Bureau of Natural Heritage Conservation, Wisconsin Department of Natural Resources, \\ Madison, WI, ${ }^{6}$ Canadian Wildlife Service, Environment and Climate Change Canada, Saskatoon, Saskatchewan, Canada
}

\begin{abstract}
Secretive marsh birds, including rails and bitterns, have experienced widespread population declines due to the loss of wetland habitat on which they depend. Because of their cryptic behavior, secretive marsh birds are challenging to study and information on their habitat requirements is limited, especially across the full annual cycle. Quantifying habitat associations throughout the annual cycle and at broad geographic scales can advance a more comprehensive approach for secretive marsh bird conservation. The goal of this study was to quantitatively synthesize results from empirical studies that examined species-habitat relationships of secretive marsh birds in the North American Mississippi Flyway to identify general patterns and information gaps that can guide future management and conservation efforts. We performed a meta-analysis and incorporated results from 40 studies that quantitatively assessed habitat associations of American Bittern (Botaurus lentiginosus), Least Bittern (Ixobrychus exilis), King Rail (Rallus elegans), Sora (Porzana carolina), Virginia Rail (Rallus limicola), and Yellow Rail(Coturnicops noveboracensis). Most studies examined breeding season habitat, whereas only $13 \%$ reported on habitat use during migration and none during winter. At landscape scales, breeding marsh birds were positively associated with amount of wetlands, especially in the Great Lakes region, and negatively associated with amount of urban land cover, particularly for American Bittern. At the local scale, breeding marsh birds were positively associated with cattail coverage (Typha spp) and other robust emergent vegetation. Overall, marsh birds were negatively associated with woody wetland vegetation, although effects were weaker in the Prairie region and varied among species. During autumn migration, moistsoil vegetation coverage was important for rails in the lower Midwest. The habitat use patterns we identified across studies provide a general characterization of marsh bird breeding habitat to aid in landscape-level multi-species conservation efforts. Our study also highlights the immediate research needs for full annual cycle conservation of secretive marsh bird habitat in North America: specifically, information during winter and migration.
\end{abstract}

\section{Associations entre l'habitat et les oiseaux de marais discrets dans la voie migratoire du Mississippi : une méta-analyse}

RÉSUMÉ. Les oiseaux de marais dits discrets, notamment les râles et les butors, ont connu une baisse généralisée de leurs populations en raison de la perte des milieux humides dont ils dépendent. Compte tenu de leur comportement cryptique, les oiseaux de marais discrets sont difficiles à étudier et les informations sur leurs besoins en matière d'habitat sont limitées, en particulier sur l'ensemble du cycle annuel. La quantification des associations avec l'habitat tout au long du cycle annuel et à de vastes échelles géographiques peut faire progresser une approche plus exhaustive de la conservation de ces oiseaux de marais. L'objectif de la présente étude était de réaliser une synthèse quantitative des résultats d'études empiriques qui ont examiné les relations entre les oiseaux de marais discrets et l'habitat dans la voie de migration nord-américaine du Mississippi, afin de déterminer les tendances générales et les lacunes en matière d'information qui pourraient guider les futures activités de gestion et de conservation. Nous avons effectué une méta-analyse et intégré les résultats de 40 études ayant évalué de façon quantitative les associations avec l'habitat du Butor d'Amérique (Botaurus lentiginosus), du Petit Blongios (Ixobrychus exilis), du Râle élégant (Rallus elegans), de la Marouette de Caroline (Porzana carolina), du Râle de Virginie (Rallus limicola) et du Râle jaune (Coturnicops noveboracensis). La plupart des études se sont penchées sur l'habitat pendant la saison de reproduction, tandis que seulement $13 \%$ ont fait état de l'utilisation de l'habitat pendant la migration et aucune pendant l'hiver. À l'échelle du paysage, les oiseaux de marais nicheurs étaient positivement associés à la quantité de milieux humides, surtout dans la région des Grands Lacs, et négativement associés à la quantité de milieux urbains, surtout pour le Butor d'Amérique. À l'échelle locale, les oiseaux de marais nicheurs étaient positivement associés au couvert de quenouilles (Typha spp.) et d'autres espèces végétales émergentes robustes. Dans l'ensemble, les oiseaux de marais étaient associés négativement à la végétation ligneuse de milieux humides, bien que les effets aient été plus faibles dans la région des Prairies et aient varié selon les espèces. Pendant la migration automnale, le couvert végétal de sols humides était important pour les râles dans le Midwest inférieur. Les tendances de l'utilisation de l'habitat que nous avons déterminées à partir des études permettent d'avoir une caractérisation générale de l'habitat de reproduction des oiseaux de marais pour guider les efforts de conservation multi-espèces au plan du paysage. Notre étude met

Correspondent author: Kristen M Malone, 301 Anheuser-Busch Natural Resources Building, Columbia, MO , United States, 65211, malonekm@missouri.edu 
également en évidence les besoins immédiats en matière de recherche pour la conservation de l'habitat d'oiseaux de marais discrets en Amérique du Nord durant le cycle annuel complet, en particulier les informations pendant l'hiver et la migration.

Key Words: American Bittern; full annual cycle conservation; King Rail; Least Bittern; Sora; Virginia Rail; Yellow Rail; wetland birds; wetland habitat management

\section{INTRODUCTION}

North America has experienced extensive wetland habitat loss over the past two centuries (Dahl 1990, Brinson and Malvárez 2002), contributing to population declines for many wetlanddependent avian species (Morrison et al. 1994, Tozer 2016, Sauer et al. 2020). For example, many states in the midwestern United States and Mississippi River watershed have lost at least $90 \%$ of wetland surface area since 1780, primarily through draining for agricultural production (Dahl 1990). Thus, migratory avian species that use interior portions of North America throughout their life cycle, such as secretive marsh birds, have likely been acutely affected by wetland habitat loss. Wetland habitat conservation efforts have predominantly focused on waterfowl (Family Anatidae) and contributed to restoration of substantial wetland habitat area in North America (North American Waterfowl Management Plan 2012, U.S. Fish and Wildlife Service 2018), but other wetland-dependent birds are often ignored in restoration efforts.

Secretive marsh birds, including rails and bitterns, are wetlanddependent species and designated species of conservation concern by many state, provincial, and federal natural resource agencies (U.S. Geological Survey 2021). Some secretive marsh bird species have experienced widespread population declines (Tozer 2016, Sauer et al. 2020), while other species' rarity and secretive nature precludes determination of their population trajectory. Secretive marsh birds can be challenging to study and monitor because they vocalize infrequently, are rarely seen, and their habitat is often inaccessible. North America's Mississippi Flyway contains critical habitat for several species of secretive marsh birds throughout their annual cycle. Breeding grounds for most of these species are located in the upper Midwest and Prairie Pothole regions, but the remainder of the Flyway provides critical migration and wintering habitats (Huschle et al. 2013, Fournier et al. 2017, Leston and Bookhout 2020).

Despite the challenges of studying secretive marsh birds, research has increased in the last decade and numerous studies have examined species-habitat relationships (Darrah and Krementz 2011, Harms and Dinsmore 2013, Glisson et al. 2015, Tozer 2016, Tozer et al. 2020). Given the dynamic and cyclic nature of wetlands, researchers have learned that marsh birds are more likely to occupy wetlands with specific habitat conditions. Understanding species-habitat relationships is a central theme in conservation ecology (Guisan and Thuiller 2005, Guisan et al. 2013) and is essential for developing effective habitat management strategies for secretive marsh birds throughout their full annual cycle. Research and management that focuses exclusively on local habitat needs may ultimately contribute to a fragmented approach that fails to adequately address management and conservation efforts at a scale sufficient to promote sustainable populations (although funding priorities also play a role). Quantifying trends in habitat associations throughout the annual cycle and at broad geographic scales, such as the flyway scale, can advance a more comprehensive approach for secretive marsh bird conservation (Martin and Finch 1995). Thus, the goal of this study was to quantitatively synthesize results from empirical studies that examined species-habitat relationships of secretive marsh birds in the Mississippi Flyway (Fig. 1) to identify general patterns and information gaps that can guide future management and conservation efforts. The flyway scale not only captures full life cycle habitat needs but is pragmatic from a conservation standpoint because the administrative flyways facilitate coordination of management and conservation actions among states and provinces within a flyway.

Fig. 1. Map of United States and Canada showing the regions within the Mississippi Flyway and distribution of studies by state/province that were included in the meta-analysis of secretive marsh bird habitat associations. The Mississippi Flyway was delineated according to the United States Fish and Wildlife Service administrative boundary. Studies were included if $>50 \%$ of the sampling locations were within the boundaries of the Mississippi Flyway. Asterisks (*) indicate states or provinces where sampling took place as part of a study that was conducted in the Mississippi Flyway.

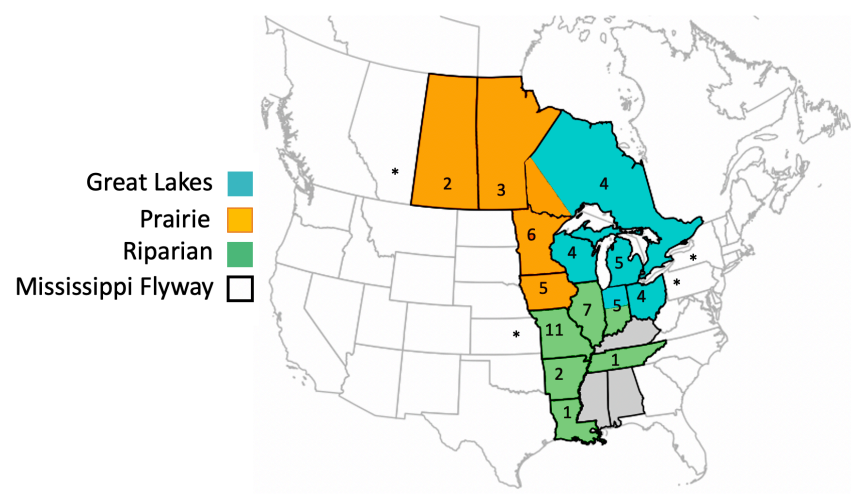

A meta-analysis is a quantitative and robust method to synthesize research findings across studies by enabling evaluation of the strength and heterogeneity in ecological patterns (Koricheva et al. 2013, Gurevitch et al. 2018). Meta-analyses that examine species-habitat associations are not common (but see Hagen et al. 2007, Hagen et al. 2013, Aubry et al. 2013) but for imperiled, understudied species, such as secretive marsh birds, a metaanalysis can be useful to wetland managers and conservation practitioners by providing insight on the broader applicability of results from individual studies. Additionally, a meta-analysis can statistically evaluate potential differences in habitat associations among factors of ecological interest, such as species, regions, or life history events, and identify information gaps that can guide future research efforts. Our objectives were to identify trends and information gaps as they relate to four main factors: 1) Species - 
how do secretive marsh bird species differ in their habitat associations and are there species-specific information gaps? 2) Region - are there regional patterns in habitat associations or information gaps? 3) Spatial scale of measurement - is the spatial scale at which habitat is measured important for determining habitat associations, and if so, do previous studies encompass the most important scale? 4) Season - how do breeding season habitat associations differ from non-breeding season habitat associations and are there seasonal information gaps?

\section{METHODS}

\section{Literature search and study selection}

We located studies by searching three online databases: Web of Science, ProQuest Theses and Dissertations, and Google Scholar. We performed searches in February 2020 and searched the full text for the following phrase ("Least Bittern" OR "American Bittern" OR "Sora” OR "Virginia Rail” OR "King Rail” OR "Yellow Rail" OR "Black Rail") and, within the same search, titles only for ("habitat" OR "ecology" OR "landscape"). To search for studies not published online, we emailed representatives of the Nongame Bird Technical Section of the Mississippi Flyway Council from each state and province within the United States Fish and Wildlife Service administrative boundaries of the Flyway. We requested representatives send us copies of reports that included any marsh bird studies carried out in their jurisdiction. Although this approach may have missed some relevant studies, it provided an unbiased method for collecting literature.

We then assessed the potential for each study to contribute quantitative data to our analysis. We initially screened studies based on titles and abstracts and excluded studies that obviously did not pertain to the subject of our search (i.e., the title or abstract indicated the study did not include our focal species, was not within the Mississippi Flyway, or did not pertain to habitat associations). Our focal species were Least Bittern (Ixobrychus exilis), American Bittern (Botaurus lentiginosus), Sora (Porzana carolina), Virginia Rail (Rallus limicola), King Rail (Rallus elegans), Yellow Rail(Coturnicops noveboracensis), and Black Rail (Laterallus jamaicensis). We further screened studies by skimming the methods and results, tables, and figures (Koricheva et al. 2013). We excluded studies not done in wetlands, studies that analyzed community metrics rather than individual species metrics, studies that provided qualitative rather than quantitative results (Koricheva et al. 2013), studies that condensed habitat variables into principal components, and studies that assessed relationships of our focal species only to habitat management actions rather than habitat features. We included studies where the response variable was any measure of population response by at least one of our focal species, including abundance, density, presence, nest presence, nest survival, or brood presence. We included studies in which the majority of sampling locations were within the United States Fish and Wildlife Service administrative boundaries of the Mississippi Flyway, even if some of the sampling locations were outside of the Flyway boundaries (Fig. 1). We excluded studies that did not report sufficient information to calculate an effect size or whose authors did not respond to our requests for missing information (Koricheva et al. 2013). We included peer-reviewed journal articles, theses and dissertations, agency reports, and unpublished manuscripts. We compared titles and authors of all potential studies to avoid duplicate studies (i.e., including studies that were first reported in a thesis, dissertation, or report and then later published in a peer-reviewed journal). A thesis or dissertation chapter that was later published in a peer-reviewed journal was considered a single study. In these cases, we first looked to the peer-reviewed material and extracted what we could. However, if some of the information was missing from the peer-reviewed publication, we looked for it in the thesis or dissertation. If most of the information we needed came from the thesis or dissertation, we cited that (Reference A1) instead of the peer-reviewed publication.

\section{Effect size extraction}

Data to calculate effect sizes were extracted from in-text results, tables, or figures. We used Pearson correlation coefficient $r$ between the species response variable and a habitat variable as our effect size estimate. Some studies reported $r$, but for many studies $r$ was calculated from other reported values. Some studies reported means and variances for habitat variables among two groups (present vs. absent, used vs. available). For these studies, we first calculated the standardized mean difference (Hedges $d$; Koricheva et al. 2013), then converted $d$ to $r$ following Koricheva et al. (2013). To calculate $d$ we extracted the mean, standard deviation (SD), and $n$ for both groups. If studies reported standard error or confidence/credible intervals, we converted those values to SD. We did not use partial $R^{2}$ or beta coefficients from multivariate models (Hullet and Levine 2003). For studies that reported results of models with multiple covariates rather than single covariates, we emailed authors and requested raw data to calculate $r$. Some studies incorporated detection probability of the focal species and although they reported results of models with multiple covariates, they indicated models with a single covariate were analyzed. In these cases, we contacted authors and asked them to share standardized beta coefficients from singlecovariate models or alternatively the raw data. If authors shared standardized beta coefficients from logistic regression, we converted them to $r$ as described in Polanin and Snilstveit (2016). If authors shared raw data, we calculated the standardized mean difference for each habitat variable between sites where each focal species was detected and sites where they were not detected, then converted the standardized mean difference to $r$.

When a study included species-specific results for multiple species, we treated these as separate observational units and extracted data for each species as independent effect sizes. Similarly, if a study was conducted during more than one annual season and presented season-specific results, we extracted data from each season as independent effect sizes. If a habitat variable was measured at multiple scales, we extracted scale-specific results as independent effect sizes. When a study was conducted across multiple years and presented results combined across years, we used the combined results. When a study presented results for individual years rather than years combined, we used results from the last year of the study (Koricheva et al. 2013). Accordingly, if authors sent us raw data in which birds and habitat were sampled at the same sites in multiple years, we used the last year of the data to calculate effect sizes.

The sample size $(n)$ associated with each effect size was the number of locations where birds and habitat were surveyed. For studies 
that compared habitat at locations where the focal species was detected versus random points, $n$ was the total number of points from both groups combined where habitat was measured. The following data were also extracted from each study to use as potential explanatory variables of effect size direction and magnitude: 1) species - one of seven focal secretive marsh bird species; 2) location - most studies were conducted across many sites, but often within one or two states or provinces; 3) season spring migration, breeding, autumn migration, or winter; 4) scale - the scale at which habitat variables were measured; 5) response variable - the population variable that was analyzed in relation to habitat variables; 6) bird survey method - the methods used to collect data on focal species; 7) habitat survey method - methods used to measure habitat variables.

We grouped studies into 3 regions within the Mississippi Flyway: Great Lakes, Prairie, and Riparian (Fig. 1). The regions were determined based on the geographic distribution of included studies and on broad differences in wetland hydrogeomorphology, which we expected to influence marsh bird habitat associations. Two studies included sampling points across more than one region and were not included in region-specific analyses.

\section{Data analysis}

Habitat variables varied across studies. Although we extracted data for every habitat variable reported in each study, we grouped and analyzed habitat variables only if the variable was measured and reported by at least 3 independent studies and was represented by at least 10 effect sizes (Higgins et al. 2020). Thus, sample sizes varied for each habitat variable. Some variables were named or measured differently across studies yet represented comparable or the same habitat feature such that we expected marsh birds to exhibit a similar association to these independent variables. For example, many studies assessed the relationship between marsh birds and the amount of emergent vegetation within a wetland, but study authors measured the amount of emergent vegetation in various ways including percent cover, density, or area of emergent vegetation within a radius around a survey point. Expecting equivalent or similar associations across different measures of the same habitat feature, we grouped these variables across studies for analysis (Table A1). Studies measured habitat at varying levels of specificity. For example, while most studies measured in some way the amount of emergent vegetation, some studies split this habitat feature into robust emergent vegetation and non-robust emergent vegetation or further into taxon-specific categories such as percent cover of Typha spp (cattail). We structured our analysis to reflect the hierarchy of measured variables (Table A2).

We grouped measurements across studies into 17 habitat variables (Tables A1 and A2). Five variables were typically measured at larger scales (median scale from 300 to $1,000 \mathrm{~m}$ ) and represented the amount of 5 landcover types surrounding the survey point or focal wetland: wetland, forest, agriculture, urban, and open water. Other variables were measured at smaller scales, typically within the focal wetland, and included the amount of non-woody emergent vegetation, robust non-woody emergent vegetation, non-robust non-woody emergent vegetation, Typha spp., woody emergent vegetation, shrubs, water depth, the interspersion of water and vegetation, wetland area, and vegetation height (Table $1)$.
We conducted random-effects meta-analyses for habitat variables that were represented by at least 10 data points and 3 studies. We first transformed correlation coefficients to Fisher's $z$ scale (Sokal and Rohlf 1995, Koricheva et al. 2013). We included study ID as a random effect in every analysis because we considered our sample of studies to represent the larger group of marsh bird studies to which we wished to generalize our results and because it accounted for non-independence of multiple effect sizes that came from the same study (Stewart 2010, Gurevitch et al. 2018). We used the restricted maximum likelihood estimator (REML) and the Hartung-Knapp adjustment for all analyses (Viechtbauer 2007, IntHout et al. 2014). We conducted all analyses with the package meta (Schwarzer 2007, Balduzzi et al. 2019) in program R (version 3.6.2; R Core Team 2019).

To determine the summary weighted-mean effect size of a habitat variable, we initially included all data points for that variable across species, regions, seasons, and measurement scales. We used $I^{2}$ to measure the percent of variability in mean effect size estimates that is due to heterogeneity rather than sampling error (Higgins and Thompson 2002). If significant heterogeneity $\left(I^{2}>\right.$ $50 \%$ ) was indicated by $I^{2}$, then we tested for effects of moderator variables univariately, including the population response variable that studies measured and moderators of primary interest to this study: season, species, region, and spatial scale. We assessed differences among response variables, seasons, species, and regions based on whether $95 \%$ Confidence Intervals (CI) of mean effect sizes overlapped among groups. We tested the effect of the scale of measurement of each habitat variable as a continuous variable using meta-regression with $p<0.05$ indicating a scale effect. If these effects explained significant variation, we reported the summary weighted-mean effect for each group that contained effect sizes from at least 3 independent studies. For each habitat variable, we subset the data by region and then analyzed each region independently for species effects. For some habitat variables, there were fewer than 3 studies representing some seasons, species, or regions and we did not report summary effects or make inference on habitat associations in those cases. We report mean effect sizes with $95 \%$ confidence intervals and consider mean effect sizes significant if confidence intervals do not overlap 0 .

Publication bias can occur in meta-analyses when studies with significant results are more likely to be published and therefore are over-represented in a meta-analysis (Rothstein et al. 2005). Some of the studies included in this meta-analysis were theses and dissertations, or agency reports, which may be less subject to the potential bias of publication in peer-reviewed journals. Nonetheless, we tested for publication bias using visual assessment of funnel plots (Koricheva et al. 2013) and by Egger's test (Egger et al. 1997), which assesses the relationship between effect size and study sample size. When publication bias was indicated by the Egger's test, we used the trim and fill method to calculate an adjusted summary effect size (Duval and Tweedie 2000).

We used an influence analysis to test for outliers within statistically significant groups. We used the "leave-one-out" method and recalculated the mean effect size $n-1$ times, each time removing one observation (Viechtbauer and Cheung 2010). If removing a single observation resulted in a mean effect size with CIs that did 
Table 1. Meta-analysis results of habitat associations of secretive marsh birds in the Mississippi Flyway. Statistically significant mean effects are indicated with an asterisk. Species, region, and season effects are listed if there were at least three studies representing the group and the confidence interval for the group-specific mean effect did not overlap 0. Species codes are AMBI = American Bittern, LEBI = Least Bittern, SORA = Sora, VIRA = Virginia Rail, KIRA = King Rail, YERA = Yellow Rail. Region abbreviations are GL $=$ Great Lakes region, $\mathrm{P}=$ Prairie region, $\mathrm{R}=$ Riparian region. $\mathrm{I} 2$ indicates the percent of variability in mean effect size estimates of a habitat variable that is due to heterogeneity rather than sampling error. $\mathrm{CI}=$ confidence interval.

\begin{tabular}{|c|c|c|c|c|c|c|c|c|c|c|}
\hline Habitat variable & $\begin{array}{c}\text { Effect } \\
\text { sizes }\end{array}$ & Studies & $\begin{array}{c}\text { Mean } \\
\text { effect size }\end{array}$ & $\begin{array}{l}\text { Lower } \\
95 \% \mathrm{CI} \\
\end{array}$ & $\begin{array}{l}\text { Upper } \\
95 \% \mathrm{CI} \\
\end{array}$ & $\mathrm{I}^{2}$ & Species & Regions & Seasons & $\begin{array}{c}\text { Median scale (min, max) } \\
\text { m }\end{array}$ \\
\hline Agriculture & 64 & 8 & -0.012 & -0.043 & 0.018 & $82.8 \%$ & $\begin{array}{l}\text { AMBI, LEBI, } \\
\text { SORA, VIRA }\end{array}$ & $\mathrm{P}$ & Breeding & $900(100,6400)$ \\
\hline Forest & 49 & 6 & $-0.046^{*}$ & -0.083 & -0.01 & $70.9 \%$ & $\begin{array}{l}\text { AMBI, LEBI, } \\
\text { SORA, VIRA }\end{array}$ & GL & Breeding & $1000(100,10,000)$ \\
\hline Wetland & 116 & 17 & $0.107^{*}$ & 0.083 & 0.131 & $79.2 \%$ & $\begin{array}{l}\text { AMBI, LEBI, } \\
\text { SORA, VIRA }\end{array}$ & GL, P & Breeding & $1000(100,10,000)$ \\
\hline Urban & 57 & 6 & $-0.118^{*}$ & -0.162 & -0.074 & $84.7 \%$ & $\begin{array}{l}\text { AMBI, LEBI, } \\
\text { SORA, VIRA }\end{array}$ & GL & Breeding & $800(100,6400)$ \\
\hline Open water & 59 & 16 & -0.026 & -0.067 & 0.016 & $82.4 \%$ & $\begin{array}{l}\text { AMBI, LEBI, } \\
\text { SORA, VIRA }\end{array}$ & $\mathrm{GL}, \mathrm{P}, \mathrm{R}$ & Breeding & $275(1,10,000)$ \\
\hline Wetland size & 15 & 6 & $0.15^{*}$ & 0.052 & 0.245 & $90.8 \%$ & $\begin{array}{l}\text { LEBI, SORA, } \\
\text { VIRA }\end{array}$ & GL & Breeding & NA \\
\hline Interspersion & 16 & 6 & $0.075^{*}$ & 0.01 & 0.139 & $48.0 \%$ & LEBI & $\mathrm{R}$ & Breeding & $50(50,1000)$ \\
\hline Water depth & 26 & 12 & $0.162^{*}$ & 0.014 & 0.304 & $95.8 \%$ & $\begin{array}{l}\text { LEBI, SORA, } \\
\text { VIRA, YERA }\end{array}$ & GL, R & $\begin{array}{l}\text { Breeding, } \\
\text { Autumn }\end{array}$ & $5(0,100)$ \\
\hline Vegetation height & 16 & 7 & 0.118 & -0.005 & 0.238 & $88.8 \%$ & $\begin{array}{l}\text { LEBI, SORA, } \\
\text { VIRA }\end{array}$ & $\mathrm{R}$ & Breeding & $5(0,50)$ \\
\hline $\begin{array}{l}\text { Non-woody emergent } \\
\text { veg. }\end{array}$ & 129 & 26 & $0.087^{*}$ & 0.037 & 0.137 & $89.9 \%$ & $\begin{array}{l}\text { AMBI, LEBI, } \\
\text { SORA, VIRA, } \\
\text { KIRA, YERA }\end{array}$ & GL, P, R & Breeding & $25(1,400)$ \\
\hline Robust emergent veg. & 41 & 13 & $0.17^{*}$ & 0.025 & 0.307 & $94.3 \%$ & $\begin{array}{l}\text { AMBI, LEBI, } \\
\text { SORA, VIRA }\end{array}$ & GL, P, R & Breeding & $50(1,100)$ \\
\hline Typha & 29 & 10 & $0.219^{*}$ & 0.098 & 0.334 & $92.6 \%$ & $\begin{array}{l}\text { AMBI, LEBI, } \\
\text { SORA, VIRA }\end{array}$ & GL, P & Breeding & $50(1,100)$ \\
\hline $\begin{array}{l}\text { Non-robust emergent } \\
\text { veg. }\end{array}$ & 55 & 13 & 0.003 & -0.042 & 0.048 & $88.3 \%$ & $\begin{array}{c}\text { AMBI, LEBI, } \\
\text { SORA, VIRA, } \\
\text { YERA }\end{array}$ & GL, R & $\begin{array}{l}\text { Breeding, } \\
\text { Autumn }\end{array}$ & $1(1,300)$ \\
\hline $\begin{array}{l}\text { Emergent veg. (non- } \\
\text { specific) }\end{array}$ & 15 & 8 & $0.165^{*}$ & 0.097 & 0.231 & $75.1 \%$ & $\begin{array}{l}\text { AMBI, LEBI, } \\
\text { SORA, VIRA }\end{array}$ & GL, R & Breeding & $100(50,400)$ \\
\hline Woody wetland veg. & 71 & 18 & $-0.109^{*}$ & -0.191 & -0.025 & $87.8 \%$ & $\begin{array}{l}\text { AMBI, LEBI, } \\
\text { SORA, VIRA, } \\
\text { KIRA, YERA }\end{array}$ & GL, P, R & Breeding & $50(1,5000)$ \\
\hline Shrubs & 13 & 5 & -0.075 & -0.152 & 0.003 & $90.5 \%$ & $\begin{array}{l}\text { AMBI, LEBI, } \\
\text { SORA }\end{array}$ & GL & Breeding & $50(100,200)$ \\
\hline $\begin{array}{l}\text { Woody wetland veg. } \\
\text { (non-specific) }\end{array}$ & 36 & 11 & -0.139 & -0.297 & 0.028 & $90.9 \%$ & $\begin{array}{c}\text { AMBI, LEBI, } \\
\text { SORA, VIRA, } \\
\text { KIRA }\end{array}$ & GL, R & Breeding & $50(1,5000)$ \\
\hline
\end{tabular}

not overlap the mean effect with all observations included, we considered that observation to be an outlier and re-analyzed the data without it.

\section{RESULTS}

The literature search returned 1,304 articles. After screening titles and abstracts for relevance and duplicates, 150 articles were left. Of these, 69 quantitatively assessed habitat associations of at least one of our focal species in the focal region, although we were only able to obtain enough information to calculate effect sizes for 41 studies. Thus, 41 studies met all our inclusion criteria for the metaanalysis (Reference A1). These were from peer-reviewed journals $(n=20 ; 49 \%)$, theses or dissertations $(n=15 ; 37 \%)$, agency reports $(n=5 ; 12 \%)$ or unpublished manuscripts $(n=1 ; 2 \%)$. We obtained missing information via email from authors of 19 studies when we could not extract information to calculate an effect size from what was reported in the study.
Most studies took place during the breeding season $(n=35 ; 85 \%)$, with the remainder occurring during autumn migration $(n=3$; $7 \%$ ), spring migration ( $n=1 ; 2 \%$ ) or during spring migration and breeding with results combined for both seasons $(n=2 ; 5 \%)$. None of the studies took place during winter. A majority of studies were conducted during or after $2010(n=28 ; 68 \%)$, whereas others took place from 2000-2009 $(n=8 ; 20 \%)$ and before $2000(n=5$; $12 \%)$. Thirty-six studies (88\%) sampled locations entirely within the Mississippi Flyway, while $5(12 \%)$ included a minority of points in neighboring states or provinces (Fig. 1). Fifteen studies $(37 \%)$ were conducted in the Great Lakes region, eight $(20 \%)$ in the Prairie region, and 17 (41\%) in the Riparian region (Fig. 1). Two studies $(5 \%)$ were conducted across more than 1 region and were not included in region-specific analyses. Black Rail was the only focal species that was not included in any study and thus not included in our analyses. 
To examine trends across 17 habitat variables, we analyzed 620 effect sizes. Habitat variables were measured using remote sensing techniques or directly in the field. The number of studies and effect sizes analyzed for different habitat variables ranged from 5-26 and 13-129, respectively (Table 1). We removed two effect sizes as outliers. We calculated most effect sizes from marsh bird detection/non-detection data $(335,54 \%)$, followed by detectionadjusted occupancy (183, 30\%), detection-adjusted abundance $(86,14 \%)$, and nest success data $(16,3 \%)$. Most studies surveyed birds using a call-broadcast point count method. We did not find evidence that effect sizes were different for any habitat variable based on the population response variable that was measured (CIs overlapped among response variables).

Across studies, secretive marsh birds were positively associated with the amount of non-woody emergent vegetation (mean effect size $=0.087, \mathrm{CI}=0.037-0.137, I^{2}=89.9 \%$ ), the amount of robust non-woody emergent vegetation (mean effect size $=0.170, \mathrm{CI}=$ $0.025-0.307, I^{2}=94.3 \%$ ), the amount of Typha spp. (mean effect size $\left.=0.219, \mathrm{CI}=0.098-0.334, I^{2}=92.6 \%\right)$, the amount of wetlands in the landscape (mean effect size $=0.107, \mathrm{CI}=0.083$ $0.131, I^{2}=79.2 \%$ ), wetland size (mean effect size $=0.15, \mathrm{CI}=$ $0.052-0.245, I^{2}=90.8 \%$ ), and water depth (mean effect size $=$ $0.162, \mathrm{CI}=0.014-0.304, I^{2}=95.8 \%$ ). Secretive marsh birds were negatively associated with the amount of urban landcover in the landscape (mean effect size $=-0.118, \mathrm{CI}=-0.162--0.074, I^{2}=$ $84.7 \%$ ), amount of forest in the landscape (mean effect size $\left.=-0.046, \mathrm{CI}=-0.083--0.01, I^{2}=70.9 \%\right)$, and amount of woody emergent vegetation (mean effect size $=-0.109$, CI $=-0.191--0.025, I^{2}=87.8 \%$; Fig. 2, Table 1). $I^{2}$ indicated heterogeneity was substantial among studies for every habitat variable except interspersion (Higgins and Thompson 2002; Table 1).

Fig. 2. Mean effect sizes (Fisher's z) representing the association of secretive marsh birds with 17 habitat variables based on meta-analysis of studies conducted in the Mississippi Flyway. Lines around the mean represent $95 \%$ confidence intervals. Sample size is indicated by shade (number of studies) and size (number of effect sizes) of points.

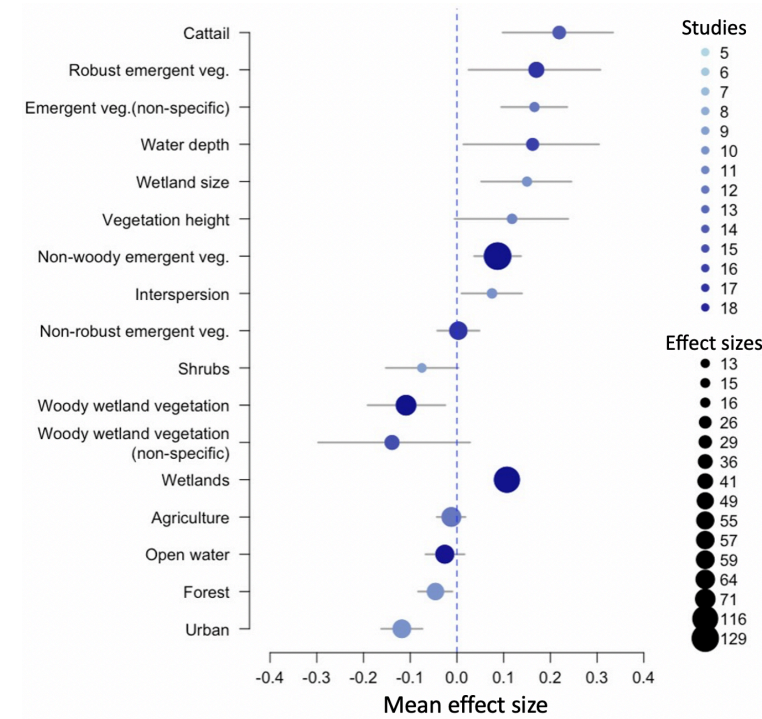

Based on the 3-study minimum, we examined region-specific associations of marsh birds to 14 habitat variables in the Great Lakes region, 7 in the Prairie region, and 10 in the Riparian region (Table 2). In the Great Lakes region water depth and the amount of Typha spp. were strongly positively associated with marsh birds (water depth mean effect size $=0.333, \mathrm{CI}=0.076-0.549, I^{2}=$ 91.5; Typha spp. mean effect size $=0.217, \mathrm{CI}=0.128-0.303, I^{2}=$ 40.8). The amount of wetlands in the landscape, wetland size, and amount of emergent vegetation (non-specific) were also positively associated with marsh birds in the Great Lakes region, whereas the amount of forest and urban landcover and the amount of shrubs were negatively associated with marsh birds in this region (Table 2; Table A3). In the Prairie region, the amount of all nonwoody emergent vegetation was strongly associated with secretive marsh birds (mean effect size $=0.219, \mathrm{CI}=0.01-0.41, I^{2}=95.9$ ). Amount of wetlands in the landscape was also positively associated with marsh birds in the Prairie region whereas the amount of open water habitat in the landscape was negatively associated (Table 2; Table A4). In the Riparian region, marsh birds were positively associated with the amount of all non-woody emergent vegetation and specifically robust emergent vegetation and negatively associated with woody emergent vegetation (Table 2; Table A5).

Table 2. Region-specific habitat associations of secretive marsh birds in the Mississippi Flyway based on meta-analysis. "..." means there were not at least 3 studies representing a specieshabitat association, "0" means 95\% confidence intervals overlapped zero, "+" indicates a significant positive relationship and "-" indicates a significant negative relationship.

\begin{tabular}{lccc}
\hline \hline Habitat variable & Great Lakes & Prairie & Riparian \\
\hline Agriculture & $\ldots$ & 0 & $\ldots$ \\
Forest & - & $\ldots$ & $\ldots$ \\
Wetland & + & + & $\ldots$ \\
Urban & - & $\ldots$ & $\ldots$ \\
Open water & 0 & - & 0 \\
Wetland size & + & $\ldots$ & $\ldots$ \\
Interspersion & $\ldots$ & $\ldots$ & 0 \\
Water depth & + & $\ldots$ & 0 \\
Vegetation height & $\ldots$ & $\ldots$ & 0 \\
Non-woody emergent veg. & 0 & + & + \\
Robust emergent veg. & 0 & 0 & + \\
Typha & + & 0 & $\ldots$ \\
Non-robust emergent veg. & 0 & $\ldots$ & 0 \\
Emergent veg. - non-specific & + & $\ldots$ & 0 \\
Woody wetland veg. & 0 & 0 & - \\
Shrubs & - & $\ldots$ & $\ldots$ \\
Woody veg. - non-specific & 0 & & - \\
\hline
\end{tabular}

Most variables for which we could compare across regions did not differ significantly by region ( $95 \%$ CIs overlapped; Appendix Figure 1). The association of marsh birds with the amount of wetlands in the landscape was significantly greater in the Great Lakes region relative to the Prairie region, although significant positive associations were present in both regions (Fig. A1).

At the species level, the number of habitat variables we examined varied by species, with few habitat variables for King Rail (3) and Yellow Rail (4), but considerably more for American Bittern (13), Least Bittern (17), Sora (16) and Virginia Rail (15; Table 3). Species differed significantly in their associations with the amount 
of agriculture in the landscape and amount of forest in the landscape (Fig. 3). Both bittern species were negatively associated with agriculture whereas Sora was positively associated with agriculture. American Bittern and Sora were negatively associated with amount of forested habitat on the landscape, whereas Virginia Rail exhibited a positive association. There were also significant differences in the magnitude of associations with the amount of wetlands in the landscape, with Virginia Rail having a significantly weaker association, although American Bittern, Least Bittern, Sora, and Virginia Rail all had significant positive associations (Fig. 3). Similarly, although all species had significant negative associations with the amount of urban landcover in the landscape, American Bittern had a significantly stronger negative association (Fig. 3).

Table 3. American Bittern (AMBI), Least Bittern (LEBI), Sora (SORA), Virginia Rail (VIRA), King Rail (KIRA) and Yellow Rail (YERA) associations with habitat variables based on metaanalysis of secretive marsh bird habitat associations in the Mississippi Flyway. “...” means there were $<3$ studies representing a species-habitat association. " 0 " means $95 \%$ confidence intervals overlapped zero. "+" indicates a significant positive relationship and "-" indicates a significant negative relationship.

\begin{tabular}{|c|c|c|c|c|c|c|}
\hline Habitat variable & AMBI & LEBI & SORA & VIRA & KIRA & YERA \\
\hline Agriculture & - & - & + & 0 & $\ldots$ & $\ldots$ \\
\hline Forest & - & 0 & - & + & $\ldots$ & $\ldots$ \\
\hline Wetland & + & + & + & + & $\ldots$ & $\ldots$ \\
\hline Urban & - & - & - & - & $\ldots$ & $\ldots$ \\
\hline Open water & 0 & 0 & 0 & 0 & $\ldots$ & $\ldots$ \\
\hline Wetland size & $\ldots$ & 0 & 0 & 0 & $\ldots$ & $\ldots$ \\
\hline Interspersion & $\ldots$ & + & $\ldots$ & $\ldots$ & $\ldots$ & $\ldots$ \\
\hline Water depth & $\ldots$ & 0 & 0 & 0 & $\ldots$ & 0 \\
\hline $\begin{array}{l}\text { Vegetation } \\
\text { height }\end{array}$ & $\ldots$ & + & 0 & 0 & $\ldots$ & $\ldots$ \\
\hline $\begin{array}{l}\text { Non-woody } \\
\text { emergent veg. }\end{array}$ & 0 & 0 & + & + & 0 & 0 \\
\hline $\begin{array}{l}\text { Robust emergent } \\
\text { veg. }\end{array}$ & 0 & 0 & + & + & $\ldots$ & $\ldots$ \\
\hline Typha & 0 & 0 & 0 & + & $\ldots$ & $\ldots$ \\
\hline $\begin{array}{l}\text { Non-robust } \\
\text { emergent veg. }\end{array}$ & 0 & 0 & 0 & 0 & $\ldots$ & 0 \\
\hline $\begin{array}{l}\text { Emergent veg. - } \\
\text { non specific }\end{array}$ & 0 & 0 & 0 & + & $\ldots$ & $\ldots$ \\
\hline $\begin{array}{l}\text { Woody wetland } \\
\text { veg. }\end{array}$ & - & 0 & 0 & 0 & 0 & 0 \\
\hline Shrubs & 0 & 0 & 0 & $\ldots$ & $\ldots$ & $\ldots$ \\
\hline $\begin{array}{l}\text { Woody veg. - } \\
\text { non-specific }\end{array}$ & - & 0 & 0 & 0 & 0 & $\ldots$ \\
\hline
\end{tabular}

Because we found few studies outside of the breeding season, we could only test for seasonal differences in marsh bird associations with two habitat variables: water depth and non-robust emergent vegetation (Table 1). The mean effect size of water depth was not different between breeding and autumn migration, whereas the mean effect size of non-robust emergent vegetation was significantly positive during autumn migration (mean effect size $\left.=0.12, \mathrm{CI}=0.055-0.184, I^{2}=89.1\right)$ but neutral during the breeding season $($ mean effect size $=-0.039, \mathrm{CI}=-0.081-0.002$, $I^{2}=58.6$ ). We did not detect differences in habitat associations according to the scale of measurement, except for the variable representing the amount of all non-woody emergent vegetation, which had a weak positive relationship to the measurement scale $(=0.0012, \mathrm{p}$-value $=0.025)$ indicating marsh bird association strength increased as measurement scale increased.

The Egger's test indicated publication bias occurred in the sample of studies used to analyze 5 habitat variables: amount of forest in the landscape, amount of all non-woody emergent vegetation, amount of non-robust emergent vegetation, vegetation height, and interspersion. We recalculated the mean effect sizes after using the trim and fill method to account for publication bias and found that although the magnitude of the effects changed, the overall conclusions drawn remained consistent (i.e., confidence intervals still either did or did not overlap 0 ). The performance of the trim and fill method may be poor when between-study heterogeneity exists, as is the case for these 5 variables, or when publication bias is absent (Peters et al. 2007). We report the original mean estimates rather than trim-and-fill revised estimates.

\section{DISCUSSION}

Our study is the first quantitative synthesis of multiple studies on secretive marsh bird habitat associations and we provide a general characterization of suitable breeding habitat to aid in landscapelevel multi-species conservation. Our study also highlights the immediate research needs for full annual cycle conservation of secretive marsh bird habitat: specifically, information during winter and migration periods of the annual cycle. We found breeding season habitat associations of secretive marsh birds were generally similar among the Great Lakes basin, Prairie, and Riparian regions of the Mississippi Flyway, although there were several important differences in habitat associations among species. Across studies throughout the Flyway, secretive marsh birds were positively associated with wetlands in the landscape and robust non-woody emergent vegetation but negatively associated with urban landcover and woody emergent vegetation.

Across studies, regions, species, and spatial scales we found secretive marsh birds were positively associated with the amount of wetland habitat in the landscape during the breeding season. Additionally, we found a positive association of secretive marsh birds with wetland size, although our inference is mostly limited to the Great Lakes region for this result. These findings align with previous work suggesting landscape composition and configuration are important considerations for waterbird conservation (Brown and Dinsmore 1986, Haig et al. 1998, Webb et al. 2010, Beatty et al. 2014, Quesnelle et al. 2015). For example, previous researchers have found isolated wetlands, even large ones, had lower species richness than wetlands that were part of a complex or near other wetlands (Brown and Dinsmore 1986, Smith and Chow-Fraser 2010) and landscape connectivity of wetlands fosters waterbird use (Guadagnin and Maltchik 2007). Although it has not been well-studied, wetland connectivity could be important for breeding secretive marsh birds because it enables within-season movements, allowing access to resources at multiple wetland sites within a complex that may not be present within a single wetland (Haig et al. 1998). Small wetlands may exclude area-dependent marsh bird species although a cluster of smaller wetlands may provide greater benefit to marsh bird populations than a single large wetland (Brown and Dinsmore 1986). Climate change may lead to further losses of wetland 
Fig. 3. Mean effect sizes (Fisher's z) representing the associations of Sora (SORA), Virginia Rail (VIRA), American Bittern (AMBI), and Least Bittern (LEBI) with habitat variables based on meta-analysis of studies conducted in the Mississippi Flyway. Lines around the mean represent 95\% confidence intervals. Sample size is indicated by shade (number of studies) and size (number of effect sizes) of points.
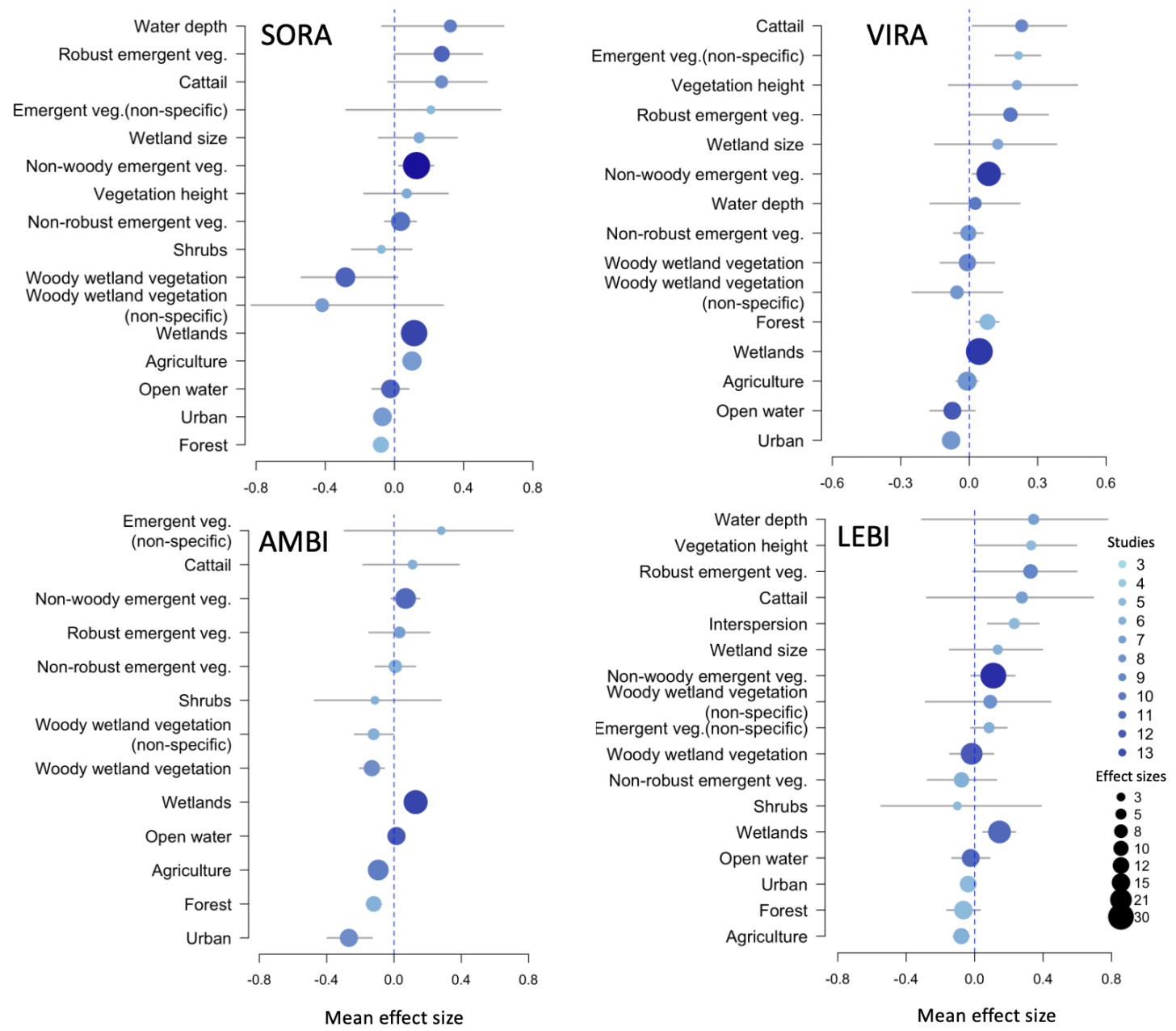

habitat as drought directly affects wetlands via drying and indirectly by intensifying other threats such as draining for agriculture (Erwin 2009). Restoration plans would benefit from incorporating potential wetland losses due to climate change.

We found negative associations with urban landcover across studies and species, although most studies were from the Great Lakes region. Similarly, distribution models developed for the breeding range of fourteen secretive marsh bird species indicated broad support for negative effects of urban development on species occupancy probability (Stevens and Conway 2020). While some wetland avian species have adapted to urban life (Martin et al. 2012, Murray et al. 2018), secretive marsh birds may be sensitive to the range of anthropogenic disturbances in urban landscapes (DeLuca et al. 2004, Schwarzbach et al. 2006, Hale et al. 2019). For instance, the natural dynamics of wetland hydrology are often disrupted in urban areas and subsequent changes in the plant community are likely to follow (Owen 1999, Wright 2005).
Our results suggest hydrological changes that diminish nonwoody emergent vegetation, in addition to wetland isolation, would make urban wetlands inhospitable for secretive marsh birds. Avoidance of urban wetlands could also be due to changes in urban predator communities (Sorace and Gustin 2009), perceived predation risk (Hua et al. 2013, Malone et al. 2017), or increased competition from generalists (DeLuca et al. 2004). Furthermore, urban wetlands are exposed to surface run-off (Owen 1998) and pollution (Hale et al. 2019), which changes the nutrient composition, plant community (Owen 1999), and the invertebrate community on which secretive marsh birds prey and could expose them to direct lethal or sub-lethal risks (i.e., ingesting trash or toxins; Blus et al. 1977, De Luca-Abbott et al. 2001, Schwarzbach et al. 2006).

We found secretive marsh birds were positively associated with robust non-woody emergent vegetation, particularly Typha, and negatively associated with woody emergent vegetation. Robust, 
perennial, non-woody emergent vegetation provides critical resources for secretive marsh birds during the breeding season, including protection from predators, nesting habitat (Lor and Malecki 2006), and food (Melvin and Gibbs 2020). Robust emergents like cattail provide ideal structure for secretive marsh birds to build above-water nesting platforms (Lor and Malecki 2006) and for above-water perching and foraging areas. Woody emergent vegetation excludes non-woody emergent vegetation and may not provide appropriate nesting substrate or cover for adults (Lor and Malecki 2006). Shrubs may provide habitat for predators (With 1996), including perching spots for avian predators like corvids (Corvidae). Thus, secretive marsh birds may avoid woody vegetation to avoid adult or nest predation by certain predators (With 1996, Winter et al. 2000, Ruth and Skagen 2017). We were unable to separate relationships of marsh birds with nonnative, invasive wetland plant species from those with native wetland plant species. Non-native, invasives such as some types of cattail (e.g. Typha angustifolia) have expanded in range and may provide the robust structure that marsh birds prefer (Glisson et al. 2015).

Across studies, we found that secretive marsh birds were positively associated with water depth during breeding and autumn migration. The relationship is likely non-linear, with a negative trend at depths beyond those often found in emergent marsh habitat $(>50 \mathrm{~cm})$, although we were unable to explore those trends in our study. The positive association with water depth likely reflects food and nest site availability as well as predator deterrence (Lowther et al. 2020). Additionally, greater water depths may be indicative of favored vegetative cover; deeper, more permanent water may allow establishment of robust emergent vegetation (Kantrud and Stewart 1984), which is preferred by secretive marsh birds.

Habitat interspersion, which is often measured as the ratio of vegetative cover to open water (high interspersion $=50: 50$ ratio), has been suggested as an important factor in secretive marsh bird site use (Weller and Spatcher 1965, Weller and Fredrickson 1973). We found a small but significant positive effect of interspersion, although because many studies we reviewed did not measure interspersion, our inference is limited to only the Least Bittern in the Riparian region of the Mississippi Flyway. However, Lor and Malecki (2006) found Least Bittern favored lower cover to water ratios relative to American Bittern, Sora, and Virginia Rail, suggesting interspersion may not be important to species other than Least Bittern. Virginia Rail use wetlands with 100\% cattail cover and thus no interspersion (Harms and Dinsmore 2013) as well as wetlands with hemi-marsh, or high interspersion, conditions (Conway 1994).

Full annual cycle habitat conservation of migratory birds depends on understanding species-habitat associations during the nonbreeding season. Eighty-five percent of the studies we included in the meta-analysis were from the breeding season; thus, we were unable to quantitatively assess broad trends for many habitat associations during migration and none during winter. Least Bitterns winter south of our focal region, but other secretive marsh bird species' winter ranges include the southernmost portion of the Mississippi Flyway. There have been several nonbreeding studies that were screened from our analysis that provide insight on localized habitat associations. Pickens and King (2014) found water depth and vegetation density were important for over-wintering Sora and American Bittern, respectively, along the Gulf Coast. Morris et al. (2017) examined habitat associations of Yellow Rail wintering in Mississippi and Alabama and found the only important predictor in their analysis was a site management characteristic - fire return interval. A Missouri study on Sora and Virginia Rail migration found that spring migrant rails were most commonly associated with dead emergent stems of beggars-tick (Bidens frondosa) and broomsedge bluestem (Andropogon virginicus), or emerging sedges and rushes, while autumn migrants were associated with pure and mixed stands of composites and annual grasses (Panicum, Echinochloa; Sayre and Rundle 1984).

From the three fall migration studies included in our metaanalysis (Fournier et al. 2017, Fournier 2017, Clark-Schubert 2009), we concluded that annual, non-robust vegetation was positively associated with marsh birds during fall migration. However, the geographic and taxonomic scope of our conclusion is still limited; all three migration studies were conducted in Missouri and involved only two of our target species (Sora and Virginia Rail). Detecting secretive marsh birds is especially challenging during non-breeding seasons (Conway et al. 1993, Conway and Gibbs 2001), although new survey methods may address this issue and facilitate future non-breeding season studies (Fournier and Krementz 2017). E-bird, a community science database, is a promising data source for mapping occurrence of rare species (Muller et al. 2018, Johnston et al. 2019) and could provide additional avenues for winter and migration habitat studies on secretive marsh birds.

Standardizing habitat measurement for marsh bird habitat studies may facilitate more collaboration and better comparison across studies (Connelly et al. 2003). The standardized marsh bird monitoring protocol (Conway 2011) was used in many of the studies we reviewed and likely influenced the increase in breeding season studies on secretive marsh birds within the last decade. Similar application of standardized marsh bird habitat measurements may have enabled our meta-analysis to investigate additional habitat characteristics, broadening the inference of this study. The large variation we found in many of the mean effect size estimates may be at least partially due to variation in metrics and methods across individual studies. With standardized habitat measurements, clearer patterns may emerge from future metaanalyses and provide additional guidance for wetland management practitioners.

\section{CONCLUSIONS}

Multi-species conservation efforts in the Mississippi Flyway, at least for American Bittern, Least Bittern, Virginia Rail, and Sora during the breeding season, may benefit by focusing on wetlands in high-density wetland landscapes or on re-connecting isolated wetlands to existing wetland complexes. Wetlands near developed or urban landcover may not be ideal targets for restoration unless conservationists find ways to make urban wetlands more hospitable to secretive marsh birds. Further research is needed to investigate the mechanisms affecting secretive marsh birds in urban wetlands and those that deter them from using wetlands near urban areas.

Based on habitat associations of marsh birds nesting in the Great Lakes region, Grand et al. (2020) developed a spatial 
prioritization to identify specific wetlands as conservation priorities. Other regions, such as the U.S. Prairie Pothole Region, have taken species-specific approaches to spatial prioritization of waterbirds (Prairie Pothole Joint Venture 2017). Similar efforts would benefit other regions of the Flyway and beyond and help prevent further loss and degradation of wetlands that provide habitat for secretive marsh birds and for a broader suite of wetland-dependent taxa. At the wetland scale, habitat management practices that promote non-woody robust emergent vegetation and minimize woody emergent vegetation (i.e., burning, disking) are likely to meet habitat requirements for multiple marsh bird species. Finally, in order to advance conservation of secretive marsh birds, more research on secretive marsh bird distributions and their habitat associations during winter and migration would fill in existing information gaps during the full annual cycle.

Responses to this article can be read online at: https://www.ace-eco.org/issues/responses.php/1924

\section{Author Contributions:}

$E B W, D M, L K, A E M$, and $S W M$ conceived the study. All authors contributed to study design. KMM collected data, performed analyses, and wrote the first draft of the manuscript. All authors contributed substantial edits to the manuscript.

\section{Acknowledgments:}

We thank the authors of the studies included in this review, particularly those that provided additional information or raw data that was not included in the published article. We thank representatives of the Non-game Bird Technical Section of the Mississippi Flyway Council for their support and feedback on this project. We thank two anonymous reviewers for their feedback on an earlier version of the manuscript. The Missouri Cooperative Fish and Wildlife Research Unit which is jointly sponsored by the Missouri Department of Conservation, the University of Missouri, the U.S. Fish and Wildlife Service, the U.S. Geological Survey, and the Wildlife Management Institute. Use of trade, firm, or product names is for descriptive purposes only and does not imply U.S. Government endorsement.

\section{LITERATURE CITED}

Aubry, K. B., C. M. Raley, S. W. Buskirk, W. J. Zielinski, M. K. Schwartz, R. T. Golightly, K. L. Purcell, R. D. Weir, and J. S. Yaeger. 2013. Meta-analyses of habitat selection by fishers at resting sites in the pacific coastal region. The Journal of Wildlife Management 77:965-974. https://doi.org/10.1002/jwmg.563

Balduzzi, S., G. Rücker, and G. Schwarzer. 2019. How to perform a meta-analysis with R: a practical tutorial. Evidence-Based Mental Health 22:153-160. https://doi.org/10.1136/ebmental-2019-300117

Beatty, W. S., D. C. Kesler, E. B. Webb, A. H. Raedeke, L. W. Naylor, and D. D. Humburg. 2014. The role of protected area wetlands in waterfowl habitat conservation: Implications for protected area network design. Biological Conservation 176:144-152. https://doi.org/10.1016/j.biocon.2014.05.018

Blus, L. J., S. N. Wiemeyer, J. A. Kerwin, R. C. Stendell, H. M. Ohlendorf, and L. F. Stickel. 1977. Impact of Estuarine Pollution on Birds. 57-71. U. S. Environmental Protection Agency, Office of Water Planning and Standards.

Brinson, M. M., and A. I. Malvárez. 2002. Temperate freshwater wetlands: types, status, and threats. Environmental Conservation 29:115-133. https://doi.org/10.1017/S0376892902000085

Brown, M., and J. J. Dinsmore. 1986. Implications of Marsh Size and Isolation for Marsh Bird Management. The Journal of Wildlife Management 50:392-397. https://doi.org/10.2307/3801093

Clark-Schubert, N. D. 2009. Fall Migration Ecology of the Sora (Porzana carolina) at Four Rivers Conservation Area in Missouri. Thesis, University of Arkansas. https://search.proquest.com/ docview/304828128/abstract/BAEC8B9854AB467BPQ/19

Connelly, J. W., K. P. Reese, and M. A. Schroeder. 2003. Monitoring of Greater Sage-grouse Habitats and Populations. Station Bulletin, Washington Department of Fish \& Wildlife, College of Natural Resources Experiment Station, Moscow, Idaho. https://wdfw.wa.gov/publications/01316 https://doi.org/10.5962/ bhl.title. 153828

Conway, C. J. 2011. Standardized North American marsh bird monitoring protocol. Waterbirds 34:319-346. https://doi. org/10.1675/063.034.0307

Conway, C. J., W. R. Eddleman, and S. H. Anderson. 1994. Nesting success and survival of Virginia Rails and Soras. The Wilson Bulletin 106:466-473.

Conway, C. J., W. R. Eddleman, S. H. Anderson, and L. R. Hanebury. 1993. Seasonal changes in Yuma Clapper Rail vocalization rate and habitat use. The Journal of Wildlife Management 57:282-290. https://doi.org/10.2307/3809425

Conway, C. J. and J. P. Gibbs. 2001. Factors Influencing Detection Probabilities and the Benefits of Call Broadcast Surveys for Monitoring Marsh Birds. Final Report, USGS Patuxent Wildlife Research Center, Laurel, Maryland. http://ag.arizona.edu/ research/azfwru/cjc/

Dahl, T. E. 1990. Wetlands Losses in the United States, 1780's to 1980's. U.S. Department of the Interior, Fish and Wildlife Service.

Darrah, A. J., and D. G. Krementz. 2011. Habitat use of nesting and brood-rearing King Rails in the Illinois and Upper Mississippi River Valleys. Waterbirds 34:160-167. https://doi. org/10.1675/063.034.0204

De Luca-Abbott, S. B., B. S. F. Wong, D. B. Peakall, P. K. S. Lam, L. Young, M. H. W. Lam, and B. J. Richardson. 2001. Review of effects of water pollution on the breeding success of waterbirds, with particular reference to Ardeids in Hong Kong. Ecotoxicology 10:327-349. https://doi.org/10.1023/A:1012288811808

DeLuca, W. V., C. E. Studds, L. L. Rockwood, and P. P. Marra. 2004. Influence of land use on the integrity of marsh bird communities of chesapeake bay, USA. Wetlands 24:837-847. 
Duval, S., and R. Tweedie. 2000. A nonparametric "trim and fill" method of accounting for publication bias in meta-analysis. Journal of the American Statistical Association 95:89-98. https:// doi.org/10.1080/01621459.2000.10473905

Egger, M., G. D. Smith, M. Schneider, and C. Minder. 1997. Bias in meta-analysis detected by a simple, graphical test. British Medical Journal 315:629-634. https://doi.org/10.1136/bmj.315.7109.629

Erwin, K. L. 2009. Wetlands and global climate change: the role of wetland restoration in a changing world. Wetlands Ecology and Management 17:71-84. https://doi.org/10.1007/s11273-008-9119-1

Fournier, A. M. V. 2017. Phenology, Habitat Use, and the Impacts of Wetland Management on Autumn Migrating Rails in Missouri. PhD Dissertation, University of Arkansas. https:// search.proquest.com/docview/1879756773/abstract/

BAEC8B9854AB467BPQ/12

Fournier, A. M. V., and D. G. Krementz. 2017. Nocturnal distance sampling all-terrain vehicle surveys for nonbreeding rails. Wildlife Society Bulletin 41:151-156. https://doi.org/10.1002/wsb.745

Fournier, A. M., D. C. Mengel, and D. G. Krementz. 2017. Virginia and Yellow Rail autumn migration ecology: synthesis using multiple data sets. Animal Migration 4:15-22. https://doi. org/10.1515/ami-2017-0003

Glisson, W. J., R. S. Brady, A. T. Paulios, S. K. Jacobi, and D. J. Larkin. 2015. Sensitivity of secretive marsh birds to vegetation condition in natural and restored wetlands in Wisconsin. The Journal of Wildlife Management 79:1101-1116. https://doi. org/10.1002/jwmg.937

Grand, J., S. P. Saunders, N. L. Michel, L. Elliott, S. Beilke, A. Bracey, T. M. Gehring, E. E. Gnass Giese, R. W. Howe, B. Kasberg, N. Miller, G. J. Niemi, C. J. Norment, D. C. Tozer, J. $\mathrm{Wu}$, and C. Wilsey. 2020. Prioritizing coastal wetlands for marsh bird conservation in the U.S. Great Lakes. Biological Conservation 249:108708. https://doi.org/10.1016/j.biocon.2020.108708

Guadagnin, D. L., and L. Maltchik. 2007. Habitat and landscape factors associated with neotropical waterbird occurrence and richness in wetland fragments. Biodiversity and Conservation 16:1231-1244. https://doi.org/10.1007/s10531-006-9127-5

Guisan, A., R. Tingley, J. B. Baumgartner, I. Naujokaitis-Lewis, P. R. Sutcliffe, A. I. T. Tulloch, T. J. Regan, L. Brotons, E. McDonald-Madden, C. Mantyka-Pringle, T. G. Martin, J. R. Rhodes, R. Maggini, S. A. Setterfield, J. Elith, M. W. Schwartz, B. A. Wintle, O. Broennimann, M. Austin, S. Ferrier, M. R. Kearney, H. P. Possingham, and Y. M. Buckley. 2013. Predicting species distributions for conservation decisions. Ecology Letters 16:1424-1435. https://doi.org/10.1111/ele.12189

Guisan, A., and W. Thuiller. 2005. Predicting species distribution: offering more than simple habitat models. Ecology Letters 8:993-1009. https://doi.org/10.1111/j.1461-0248.2005.00792.x

Gurevitch, J., J. Koricheva, S. Nakagawa, and G. Stewart. 2018. Meta-analysis and the science of research synthesis. Nature 555:175-182. https://doi.org/10.1038/nature25753
Harms, T. M., and S. J. Dinsmore. 2013. Habitat associations of secretive marsh birds in Iowa. Wetlands 33:561-571. https://doi. org/10.1007/s13157-013-0414-0

Hagen, C. A., J. W. Connelly, and M. A. Schroeder. 2007. A Metaanalysis of Greater Sage-grouse, Centrocercus urophasianus, nesting and brood-rearing habitats. Wildlife Biology 13:42-50. https://doi.org/10.2981/0909-6396(2007)13[42:AMOGSC]2.0.CO;2

Hagen, C. A., B. A. Grisham, C. W. Boal, and D. A. Haukos. 2013. A meta-analysis of lesser prairie-chicken nesting and broodrearing habitats: Implications for habitat management. Wildlife Society Bulletin 37:750-758. https://doi.org/10.1002/wsb.313

Haig, S. M., D. W. Mehlman, and L. W. Oring. 1998a. Avian movements and wetland connectivity in landscape conservation. Conservation Biology 12:749-758. https://doi.org/10.1111/ j.1523-1739.1998.97102.x

Hale, R., S. E. Swearer, M. Sievers, and R. Coleman. 2019. Balancing biodiversity outcomes and pollution management in urban stormwater treatment wetlands. Journal of Environmental Management 233:302-307. https://doi.org/10.1016/j.jenvman.2018.12.064

Higgins, J. P. T., J. Thomas, J. Chandler, M. Cumpston, T. Li, M. J. Page, and V. A. Welch 2020. Cochrane handbook for systematic reviews of interventions version 6.1 (updated September 2020). Cochrane, 2020. Available from www.training.cochrane.org/ handbook.

Higgins, J. P. T., and S. G. Thompson. 2002. Quantifying heterogeneity in a meta-analysis. Statistics in Medicine 21:1539-1558. https://doi.org/10.1002/sim.1186

Hua, F., K. E. Sieving, R. J. Fletcher, and C. A. Wright. 2014. Increased perception of predation risk to adults and offspring alters avian reproductive strategy and performance. Behavioral Ecology 25:509-519. https://doi.org/10.1093/beheco/aru017

Hullett, C. R., and T. R. Levine. 2003. The overestimation of effect sizes from $F$ values in meta-analysis: the cause and a solution. Communication Monographs 70:52-67.

Huschle, G., J. E. Toepfer, and D. C. Douglas. 2013. Migration and wintering areas of American Bitterns (Botaurus lentiginosus) that summer in central North America as determined by satellite and radio telemetry, 1998-2003. Waterbirds 36:300-309. https:// doi.org/10.1675/063.036.0307

Johnston, A., W. Hochachka, M. Strimas-Mackey, V. Ruiz Gutierrez, O. Robinson, E. Miller, T. Auer, S. Kelling, and D. Fink. 2019. Analytical guidelines to increase the value of citizen science data: using eBird data to estimate species occurrence. preprint. Ecology. http://biorxiv.org/lookup/doi/10.1101/574392 https://doi.org/10.1101/574392

IntHout, J., J. P. Ioannidis, and G. F. Borm. 2014. The HartungKnapp-Sidik-Jonkman method for random effects meta-analysis is straightforward and considerably outperforms the standard DerSimonian-Laird method. BMC Medical Research Methodology 14:25. https://doi.org/10.1186/1471-2288-14-25

Kantrud, H. A., and R. E. Stewart. 1984. Ecological distribution and crude density of breeding birds on prairie wetlands. The 
Journal of Wildlife Management 48:426. https://doi. org/10.2307/3801174

Koricheva, J., J. Gurevitch, and K. Mengersen. 2013. Handbook of Meta-analysis in Ecology and Evolution. Princeton University Press.

Leston, L., and T. A. Bookhout. 2020. Yellow Rail (Coturnicops noveboracensis). Birds of the World. https://birdsoftheworld.org/ bow/species/yelrai/cur/introduction Accessed 27 Oct 2020.

Lor, S., and R. A. Malecki. 2006. Breeding ecology and nesting habitat associations of fve marsh bird species in western New York. Waterbirds 29:427-436. https://doi.org/10.1675/1524-4695 (2006)29[427:BEANHA]2.0.CO;2

Lowther, P. E., A. F. Poole, J. P. Gibbs, S. M. Melvin, and F. A. Reid. 2020. American Bittern (Botaurus lentiginosus). Birds of the World. https://birdsoftheworld.org/bow/species/amebit/cur/ introduction>. Accessed 25 Oct 2020.

Malone. K. M., A. C. Powell, F. Hua, and K. E. Sieving. 2017. Bluebirds perceive prey switching by Cooper's Hawks across an urban gradient and adjust reproductive effort. Ecoscience 24:21-31. https://doi.org/10.1080/11956860.2017.1346449

Martin, J., K. French, and R. Major. 2012. Behavioural adaptation of a bird from transient wetland specialist to an urban resident. PLOS ONE 7:e50006. https://doi.org/10.1371/journal. pone. 0050006

Martin, T. E., and D. M. Finch. 1995. Ecology and Management of Neotropical migratory birds: a Synthesis and Review of Critical Issues. Oxford University Press.

Melvin, S. M., and J. P. Gibbs. 2020. Sora (Porzana carolina). Birds of the World. <https://birdsoftheworld.org/bow/species/ sora/cur/introduction>. Accessed 25 Oct 2020.

Morris, K. M., M. S. Woodrey, S. G. Hereford, E. C. Soehren, T. J. Conkling, and S. A. Rush. 2017. Yellow Rail (Coturnicops noveboracensis) occupancy in the context of fire in Mississippi and Alabama, USA. Waterbirds 40:95-104. https://doi. org/10.1675/063.040.0202

Morrison, R. I. G., C. Downes, and B. Collins. 1994. Population trends of shorebirds on fall migration in eastern Canada 1974-1991. The Wilson Bulletin 106:431-447.

Muller, J. A., J. A. Veech, and R. M. Kostecke. 2018. Landscapescale habitat associations of Sprague's Pipits wintering in the southern United States. Journal of Field Ornithology 89:326-336. https://doi.org/10.1111/jofo.12271

Murray, M. H., A. D. Kidd, S. E. Curry, J. Hepinstall-Cymerman, M. J. Yabsley, H. C. Adams, T. Ellison, C. N. Welch, and S. M. Hernandez. 2018. From wetland specialist to hand-fed generalist: shifts in diet and condition with provisioning for a recently urbanized wading bird. Philosophical Transactions of the Royal Society B: Biological Sciences 373:20170100. https://doi. org/10.1098/rstb.2017.0100

NAWMP. 2012. North American Waterfowl Management Plan. https://www.fws.gov/migratorybirds/pdf/management/ NAWMP/2012NAWMP.pdf
Owen, C. R. 1998. Hydrology and history: land use changes and ecological responses in an urban wetland. Wetlands Ecology and Management 6:209-219. https://doi.org/10.1023/A:1008488022466

Owen, C. R. 1999. Importance of Hydrology, Water quality, and Disturbance to the Northern Basin Marsh Ecosystem of Grassy Pond, Litchfield, NH. Report submitted to The Nature Conservancy, Concord, NH.

Peters, J. L., A. J. Sutton, D. R. Jones, K. R. Abrams, and L. Rushton. 2007. Performance of the trim and fill method in the presence of publication bias and between-study heterogeneity. Statistics in Medicine 26:4544-4562. https://doi.org/10.1002/ sim. 2889

Pickens, B. A., and S. L. King. 2014. Multiscale habitat selection of wetland birds in the northern Gulf Coast. Estuaries and Coasts 37:1301-1311. https://doi.org/10.1007/s12237-013-9757-2

Polanin, J. R., and B. Snilstveit. 2016. Converting between effect sizes. Campbell Systematic Reviews 12:1-13. https://doi. org/10.4073/cmpn.2016.3

Prairie Pothole Joint Venture. 2017. Prairie Pothole Joint Venture Implementation Plan. S. P. Fields, editor. U.S. Fish and Wildlife Service, Denver, Colorado, USA.

Quesnelle, P. E., K. E. Lindsay, and L. Fahrig. 2015. Relative effects of landscape-scale wetland amount and landscape matrix quality on wetland vertebrates: a meta-analysis. Ecological Applications 25:812-825. https://doi.org/10.1890/14-0362.1

R Core Team. 2019. R: A language and environment for statistical computing. R

Foundation for Statistical Computing, Vienna, Austria. URL https://www.R-project.org/.

Rothstein, H. R., A. J. Sutton, and M. Borenstein. 2005. Publication Bias in Meta-analysis: Prevention, Assessment and Adjustments. John Wiley \& Sons, Ltd. https://doi. org/10.1002/0470870168

Ruth, J. M., and S. K. Skagen. 2017. Territory and nest site selection patterns by Grasshopper Sparrows in southeastern Arizona. The Condor 119:469-483. https://doi.org/10.1650/ CONDOR-16-210.1

Sauer, J. R., W. A. Link, and J. E. Hines. 2020. The North American Breeding Bird Survey, Analysis Results 1966 - 2019: U. S. Geological Survey data release.

Sayre, M. W., and W. D. Rundle. 1984. Comparison of habitat use by migrant soras and Virginia rails. The Journal of Wildlife Management 48:599-605. https://doi.org/10.2307/3801198

Schwarzbach, S. E., J. D. Albertson, and C. M. Thomas. 2006. Effects of predation, flooding, and contamination on reproductive success of California Clapper Rails (Rallus longirostris obsoletus) in San Francisco Bay. The Auk 123:45-60. https://doi.org/10.1093/auk/123.1.45

Schwarzer, G. 2007. meta: An R Package for Meta-Analysis. Rnews 2007-3. https://cran.rstudio.org/doc/Rnews/Rnews_2007-3. pdf\#page $=40$ 
Smith, L. A., and P. Chow-Fraser. 2010. Impacts of adjacent land use and isolation on marsh bird communities. Environmental Management 45:1040-1051. https://doi.org/10.1007/s00267-010-9475-5

Sokal, R. R. , and F. J. Rohlf. 1995. Biometry: The Principles and Practice of Statistics in Biological Research. 3rd ed. Freeman, New York, New York.

Sorace, A., and M. Gustin. 2009. Distribution of generalist and specialist predators along urban gradients. Landscape and Urban Planning 90:111-118. https://doi.org/10.1016/j.landurbplan.2008.10.019

Stevens B. S., and C. J. Conway. 2020. Predictive multi-scale occupancy models at range-wide extents: effects of habitat and human disturbance on distributions of wetland birds. Diversity and Distributions 26:34-48. https://doi.org/10.1111/ddi.12995

Stewart, G. 2010. Meta-analysis in applied ecology. Biology Letters 6:78-81. https://doi.org/10.1098/rsbl.2009.0546

Tozer, D. C. 2016. Marsh bird occupancy dynamics, trends, and conservation in the southern Great Lakes basin: 1996 to 2013. Journal of Great Lakes Research 42:136-145. https://doi. org/10.1016/j.jglr.2015.10.015

Tozer, D. C., R. L. M. Stewart, O. Steele, and M. Gloutney. 2020. Species-habitat relationships and priority areas for marshbreeding birds in Ontario. The Journal of Wildlife Management 84:786-801. https://doi.org/10.1002/jwmg.21840

U.S. Fish and Wildlife Service. 2018. Waterfowl Population Status, 2018. U.S. Department of the Interior, Washington, D.C. USA 80.

U.S. Geological Survey. 2021. State wildlife action plans: A national look at Species of Greatest Conservation Need as reported in State Wildlife Action Plans. https://www1.usgs.gov/ csas/swap/index.html, accessed April 2021.

Viechtbauer, W. 2007. Publication bias in meta-analysis: prevention, assessment and adjustments. Psychometrika 72:269-271. https://doi.org/10.1007/s11336-006-1450-y

Viechtbauer, W., and M. W. Cheung. 2010. Outlier and influence diagnostics for meta-analysis. Research Synthesis Methods 1:112-125. https://doi.org/10.1002/jrsm.11

Winter, M., D. H. Johnson, and J. Faaborg. 2000. Evidence for edge effects on multiple levels in tallgrass prairie. The Condor 102:256-266. https://doi.org/10.1093/condor/102.2.256

With, K. A. 1996. The hazards of nesting near shrubs for a grassland bird, the McCown's Longspur. The Condor 96:1009-1019. https://doi.org/10.2307/1369110

Webb, E. B., L. M. Smith, M. P. Vrtiska, and T. G. Lagrange. 2010. Effects of local and landscape variables on wetland bird habitat use during migration through the rainwater basin. The Journal of Wildlife Management 74:109-119. https://doi. org/10.2193/2008-577

Weller, M., and C. Spatcher. 1965. Role of habitat in the distribution and abundance of marsh birds. Special Report. https://lib.dr.iastate.edu/specialreports/42

Weller, M. W., and L. H. Fredrickson. 1973. Avian ecology of a managed glacial marsh. The Living Bird, Twelfth Annual of the Cornell Laboratory of Ornithology, Cornell University, Ithaca, New York p 269-291.

Wright, J. D. 2005. The Evaluation and Modeling of the Effects of Surface Treatments on the Hydrology of a Restored Wetland in the Coastal Plain of North Carolina. Thesis - North Carolina State University.
Editor-in-Chief: Alexander L.Bond Subject Editor: Scott Wilson
Sponsored by the Society of Canadian Ornithologists and Birds Canada

Parrainée par la Société des ornithologistes du Canada et Oiseaux Canada

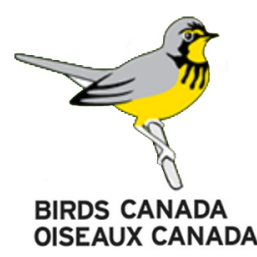


APPENDIX

2 Appendix 1. Supplementary material on the variables examined, region-specific results, and

3 studies included in the meta-analysis.

Table A1. Landscape habitat variables examined for associations with marsh birds in the

Mississippi Flyway and the specific metrics used across studies that were grouped for metaanalyses.

\begin{tabular}{|c|c|}
\hline Habitat variable & Study \\
\hline \multicolumn{2}{|l|}{ Amount of agriculture } \\
\hline $\begin{array}{l}\text { Percent cover cultivated } \\
\text { land }\end{array}$ & Hay and Manseau 2007 \\
\hline Percent cover agriculture & $\begin{array}{l}\text { Valente et al. 2011, Martin 2012, Tozer 2016, Harms et } \\
\text { al. 2017, Saunders et al. 2019, Tozer et al. } 2020\end{array}$ \\
\hline Patch density of agriculture & Harms et al. 2017 \\
\hline Cropland area & Prairie Habitat Joint Venture 2014 \\
\hline \multicolumn{2}{|l|}{ Amount of wetlands } \\
\hline Percent cover marsh & $\begin{array}{l}\text { Hay and Manseau 2007, Smith-Cartwright and Chow- } \\
\text { Fraser 2012, Tozer et al. } 2020\end{array}$ \\
\hline Percent cover wet meadow & Hay and Manseau 2007, Hansen 2019 \\
\hline $\begin{array}{l}\text { Percent cover emergent } \\
\text { wetland }\end{array}$ & $\begin{array}{l}\text { Scott 2010, Monfils and Corace 2018, Saunders et al. } \\
2019\end{array}$ \\
\hline Percent cover wetland & $\begin{array}{l}\text { Budd and Krementz 2010, Kahler 2013, Glisson et al. } \\
\text { 2015, Tozer 2016, Harms et al. } 2017\end{array}$ \\
\hline Area of wetland habitat & $\begin{array}{l}\text { Harms and Dinsmore 2013, Prairie Habitat Joint } \\
\text { Venture 2014, Tozer } 2016\end{array}$ \\
\hline Percent cover marsh/fen & Martin 2012 \\
\hline Wetland count & Prairie Habitat Joint Venture 2014 \\
\hline Wetland density & Mushanski 2015 \\
\hline \multicolumn{2}{|l|}{ Amount of forest } \\
\hline Percent cover forest & $\begin{array}{l}\text { Budd and Krementz 2010, Smith-Cartwright and Chow- } \\
\text { Fraser 2012, Kahler 2013, Glisson et al. 2015, Tozer et } \\
\text { al. } 2020\end{array}$ \\
\hline $\begin{array}{l}\text { Percent cover mixed wood } \\
\text { forest }\end{array}$ & Martin 2012 \\
\hline \multicolumn{2}{|l|}{ Amount of open water } \\
\hline Percent cover open water & $\begin{array}{l}\text { Winstead and King 2006, Scott 2010, Bolenbaugh et al. } \\
\text { 2011, Harms and Dinsmore 2013, Glisson et al. 2015, } \\
\text { Hill Chpt } 2 \text { 2015, Tozer 2016, Monfils and Corace } 2018\end{array}$ \\
\hline Percent cover water & $\begin{array}{l}\text { Hay and Manseau 2007, Clark-Schubert 2009, Valente } \\
\text { et al. 2011, Harms et al. 2017, Hansen 2019, }\end{array}$ \\
\hline Area open water & Moore 2000 \\
\hline $\begin{array}{l}\text { Percent aquatic bed/open } \\
\text { water wetland }\end{array}$ & Kahler 2013 \\
\hline Largest patch index of water & Harms et al. 2017 \\
\hline Water area & Prairie Habitat Joint Venture 2014 \\
\hline Amount of urban & \\
\hline
\end{tabular}




\begin{tabular}{cl}
\hline Percent cover urban & $\begin{array}{l}\text { Smith-Cartwright and Chow-Fraser 2012, Tozer 2016, } \\
\text { Tozer et al. 2020 } \\
\text { Sercent cover development } \\
\begin{array}{c}\text { Sercent cover developed } \\
\text { (low-intensity) }\end{array} \\
\begin{array}{c}\text { Area of urban, road, built- } 2019 \\
\text { up, or barrenland }\end{array}\end{array}$ \\
\hline
\end{tabular}


10 Table A2. Local scale habitat variables examined for associations with marsh birds in the 11 Mississippi Flyway and the specific metrics used across studies that were grouped for meta12 analyses.

\begin{tabular}{|c|c|}
\hline Habitat variable & Study \\
\hline \multicolumn{2}{|l|}{ Wetland Size } \\
\hline Wetland size & $\begin{array}{l}\text { Chandler and Weiss 1995, Tozer et al. 2010, } \\
\text { Smith-Cartwright and Chow-Fraser 2012, Harms } \\
\text { and Dinsmore 2013, Mushanski 2015, Tozer } \\
2016\end{array}$ \\
\hline \multicolumn{2}{|l|}{ Interspersion } \\
\hline $\begin{array}{l}\text { Interspersion of water and } \\
\text { vegetation }\end{array}$ & $\begin{array}{l}\text { Darrah and Krementz 2009, Bolenbaugh et al. } \\
2011\end{array}$ \\
\hline Edge density of wetland & Harms et al. 2017 \\
\hline Edge density of water & Harms et al. 2017 \\
\hline Percent cover interspersion & Darrah and Krementz 2010 \\
\hline Robust emergent vegetation edge & Moore 2000 \\
\hline Edge index & Moore 2000 \\
\hline Open water edge & Moore 2000 \\
\hline Soil-water interface & Clark-Schubert 2009 \\
\hline Vegetation interface & Clark-Schubert 2009 \\
\hline \multicolumn{2}{|l|}{ Water Depth } \\
\hline Water depth & $\begin{array}{l}\text { Johnson and Dinsmore 1986, Reid 1989, Clark- } \\
\text { Schubert 2009, Tozer et al. 2010, Darrah and } \\
\text { Krementz 2011, Martin 2012, Austin and Buhl } \\
\text { 2013, Harms and Dinsmore 2013, Hill Chpt } 1 \\
\text { 2015, Hill Chpt } 2 \text { 2015, Fournier 2017, Monfils } \\
\text { and Corace 2018, Hansen } 2019\end{array}$ \\
\hline Water depth in cover & Moore 2000 \\
\hline \multicolumn{2}{|l|}{ Vegetation Height } \\
\hline Vegetation height & $\begin{array}{l}\text { Johnson and Dinsmore 1986, Clark-Schubert } \\
\text { 2009, Martin 2012, Hill Chpt } 1 \text { 2015, Hill Chpt } \\
2 \text { 2015, }\end{array}$ \\
\hline Maximum vegetation height & $\begin{array}{l}\text { Martin 2012, Harms and Dinsmore 2013, } \\
\text { Monfils and Corace } 2018\end{array}$ \\
\hline \multicolumn{2}{|l|}{ Non-woody emergent vegetation } \\
\hline \multicolumn{2}{|l|}{ Robust } \\
\hline Area robust emergent cover & Moore 2000 \\
\hline Percent cover cattails and bulrush & Mushanski 2015 \\
\hline $\begin{array}{l}\text { Percent cover persistent deep-water } \\
\text { emergents }\end{array}$ & Monfils and Corace 2018, \\
\hline $\begin{array}{l}\text { Percent cover persistent shallow- } \\
\text { water emergents }\end{array}$ & Monfils and Corace 2018, \\
\hline Percent cover persistent vegetation & Hansen 2019 \\
\hline $\begin{array}{l}\text { Percent cover persistent emergent } \\
\text { vegetation }\end{array}$ & Blake-Bradshaw 2018 \\
\hline
\end{tabular}


Percent cover robust emergent vegetation

Percent cover bulrush Typha

Percent cover Typha spp

Typha spp stems

Non-robust

Percent cover non-robust short emergent vegetation $<0.75 \mathrm{~m}$

Percent cover non-robust tall emergent vegetation $>0.75 \mathrm{~m}$

Percent cover non-persistent vegetation (non-woody)

Percent cover annual moist soil vegetation

Percent cover non-persistent emergent vegetation

Percent cover perennial moist soil vegetation

Percent cover Polygonum spp.

Percent cover Echinochloa spp.

Percent cover Eleochris spp.

Percent cover Phalaris spp.

Percent cover Carex spp.

Percent cover grass/weeds

Percent cover sedge-bluejoint grass

Percent cover non-persistent shallow-water emergents

Percent cover sedge

Sedge stems

Herb stems

Percent cover grass

Percent cover forbs

Grass stems

Emergent vegetation (non-specific)

Percent cover emergent herbaceous wetland

Percent cover emergent herbaceous vegetation

Percent cover other emergents

Percent cover short emergent $(<1 \mathrm{~m})$
Valente et al. 2011

Chandler and Weiss 1995, Moore 2000, Kirk et al. 2001, Hay and Manseau 2007, Brittain and Thieme 2011, Martin 2012, Harms and

Dinsmore 2013, Glisson et al. 2015, Hansen

2019

Brittain and Thieme 2011

Valente et al. 2011

Valente et al. 2011

Hansen 2019

Fournier 2017

Blake-Bradshaw 2018

Fournier 2017

Clark-Schubert 2009

Clark-Schubert 2009

Clark-Schubert 2009

Glisson et al. 2015

Monfils and Corace 2018

Valente et al. 2011

Austin and Buhl 2013

Monfils and Corace 2018

Brittain and Theime 2011, Harms and Dinsmore 2013

Brittain and Theime 2011

Brittain and Theime 2011

Kirk et al. 2001, Brittain and Theime 2011

Martin 2012

Brittain and Theime 2011

\section{Scott 2010}

Glisson et al. 2015, Tozer 2016

Winstead and King 2006

Darrah and Krementz 2009 
Percent cover tall emergent $(>1 \mathrm{~m})$

Percent cover emergent vegetation

Proportion rank emergent vegetation (Typha, Carex, Juncus, Schoenoplectus)
Darrah and Krementz 2009, Darrah and

Krementz 2010

Kirk et al. 2001, Hill Chpt 2 2015,

Budd and Krementz 2010

\begin{tabular}{ll}
\hline Woody emergent vegetation & \\
\hline Shrubs & \\
\hline $\begin{array}{c}\text { Percent cover trees/shrubs } \\
\text { Proportion cover scrub/shrub } \\
\text { wetland }\end{array}$ & Kirk et al. 2001, Tozer 2016 \\
Percent cover trees $<3 \mathrm{~m}$ & Valente et al. 2011 \\
Percent cover shrubs & Martin 2012 \\
\hline Non-specific & \\
\hline Percent cover woody vegetation & Winstead and King 2006, Darrah and Krementz \\
& 2009, Darrah and Krementz 2010, Bolenbaugh \\
& et al. 2011, Brittain and Thieme 2011, Harms \\
& and Dinsmore 2013, Monfils and Corace 2018, \\
& Hansen 2019 \\
Woody stems & Brittain and Thieme 2011 \\
Woody wetland area & Bolenbaugh et al. 2011 \\
Proportion forested wetland & Monfils and Corace 2018 \\
Percent cover woody wetland & Bolenbaugh et al. 2012 \\
Percent cover lowland woody & Austin and Buhl 2013 \\
\hline
\end{tabular}


15 Table A3. Great Lakes region: Summary effect sizes for the relationships of habitat to secretive marsh birds in the Great Lakes

16 region. Asterisks indicate statistically significant mean effect sizes (95\% confidence intervals did not overlap 0). Values are not

17 reported when there were $<3$ studies for a variable or species. Species codes are AMBI $=$ American Bittern, LEBI $=$ Least Bittern,

$18 \mathrm{SORA}=$ Sora, VIRA $=$ Virginia Rail. $I^{2}$ indicates the percent of variability in mean effect size estimates of a habitat variable that is

19 due to heterogeneity rather than sampling error.

\begin{tabular}{|c|c|c|c|c|c|c|c|c|}
\hline \multirow[b]{2}{*}{ Habitat variable } & \multicolumn{2}{|l|}{ Number of } & \multirow[b]{2}{*}{ Mean effect size } & \multirow[b]{2}{*}{$\mathrm{I}^{2}$} & \multicolumn{4}{|c|}{ Mean effect size for species } \\
\hline & Effect sizes & Studies & & & AMBI & LEBI & SORA & VIRA \\
\hline Agriculture & 36 & 2 & - & - & - & - & - & - \\
\hline Forest & 47 & 4 & $\begin{array}{l}-0.041^{*} \\
(-0.077 ;-0.004)\end{array}$ & $71.3 \%$ & $\begin{array}{l}-0.12^{*} \\
(-0.164 ;-0.076)\end{array}$ & $\begin{array}{l}-0.053 \\
(-0.152 ; 0.048)\end{array}$ & $\begin{array}{l}-0.079 * \\
(-0.105 ;-0.052)\end{array}$ & $\begin{array}{l}0.08^{*} \\
(0.03 ; 0.129)\end{array}$ \\
\hline Wetland & 64 & 8 & $\begin{array}{l}0.147 * \\
(0.112 ; 0.181)\end{array}$ & $78.0 \%$ & $\begin{array}{l}0.183 * \\
(0.13 ; 0.235)\end{array}$ & $\begin{array}{l}0.205^{*} \\
(0.069 ; 0.334)\end{array}$ & $\begin{array}{l}0.151^{*} \\
(0.108 ; 0.193)\end{array}$ & $\begin{array}{l}0.059^{*} \\
(0.02 ; 0.098)\end{array}$ \\
\hline Urban & 39 & 4 & $\begin{array}{l}-0.162 * \\
(-0.225 ;-0.098)\end{array}$ & $86.7 \%$ & $\begin{array}{l}-0.409 * \\
(-0.546 ;-0.25)\end{array}$ & $\begin{array}{l}-0.037 * \\
(-0.072 ;-0.003)\end{array}$ & $\begin{array}{l}-0.078 * \\
(-0.092 ;-0.064)\end{array}$ & $\begin{array}{l}-0.123 * \\
(-0.147 ;-0.1)\end{array}$ \\
\hline Open water & 21 & 5 & $\begin{array}{l}-0.02 \\
(-0.102 ; 0.064)\end{array}$ & $88.3 \%$ & $\begin{array}{l}0.0080 \\
(-0.080 ; 0.095)\end{array}$ & - & $\begin{array}{l}-0.006 \\
(-0.254 ; 0.243)\end{array}$ & $\begin{array}{l}-0.132 \\
(-0.347 ; 0.097)\end{array}$ \\
\hline Wetland size & 12 & 4 & $\begin{array}{l}0.194 * \\
(0.077 ; 0.306)\end{array}$ & $92.0 \%$ & - & $\begin{array}{l}0.265^{*} \\
(0.171 ; 0.355)\end{array}$ & $\begin{array}{l}0.175 \\
(-0.156 ; 0.47)\end{array}$ & $\begin{array}{l}0.161 \\
(-0.237 ; 0.513)\end{array}$ \\
\hline Interspersion & 0 & 0 & - & - & - & - & - & - \\
\hline Water depth & 13 & 5 & $\begin{array}{l}0.333 * \\
(0.076 ; 0.549)\end{array}$ & $91.5 \%$ & - & - & $\begin{array}{l}0.446 \\
(-0.376 ; 0.875)\end{array}$ & $\begin{array}{l}0.104 \\
(-0.302 ; 0.478)\end{array}$ \\
\hline Vegetation height & 5 & 2 & - & - & - & - & - & - \\
\hline Non-woody emergent veg. & 40 & 7 & $\begin{array}{l}0.106 \\
(-0.024 ; 0.233)\end{array}$ & $91.7 \%$ & $\begin{array}{l}0.102 \\
(-0.085 ; 0.281)\end{array}$ & $\begin{array}{l}0.273 \\
(-0.188 ; 0.635)\end{array}$ & $\begin{array}{l}0.139 \\
(-0.064 ; 0.331)\end{array}$ & $\begin{array}{l}0.111 \\
(-0.03 ; 0.248)\end{array}$ \\
\hline Robust emergent veg. & 18 & 5 & $\begin{array}{l}0.1 \\
(-0.179 ; 0.365)\end{array}$ & $93.5 \%$ & & & $\begin{array}{l}0.255 \\
(-0.217 ; 0.63)\end{array}$ & $\begin{array}{l}0.167 \\
(-0.067 ; 0.383)\end{array}$ \\
\hline Typha & 9 & 4 & $\begin{array}{l}0.217^{*} \\
(0.128 ; 0.303)\end{array}$ & $40.8 \%$ & - & - & $\begin{array}{l}0.136 \\
(-0.057 ; 0.32)\end{array}$ & $\begin{array}{l}0.31 * \\
(0.132 ; 0.469)\end{array}$ \\
\hline Non-robust emergent veg. & 13 & 5 & $\begin{array}{l}0.016 \\
(-0.134 ; 0.165)\end{array}$ & $83.6 \%$ & - & - & $\begin{array}{l}0.0001 \\
(-0.273 ; 0.273)\end{array}$ & - \\
\hline Emergent veg. (non-specific) & 9 & 3 & $\begin{array}{l}0.18^{*} \\
(0.087 ; 0.27)\end{array}$ & $82.9 \%$ & $\begin{array}{l}0.281 \\
(-0.294 ; 0.707)\end{array}$ & - & - & $\begin{array}{l}0.216^{*} \\
(0.115 ; 0.312)\end{array}$ \\
\hline Wetland woody veg. & 21 & 5 & $\begin{array}{l}-0.208 \\
(-0.466 ; 0.082)\end{array}$ & $95.4 \%$ & $\begin{array}{l}-0.12 \\
(-0.29 ; 0.057)\end{array}$ & $\begin{array}{l}0.274 \\
(-0.949 ; 0.983)\end{array}$ & $\begin{array}{l}-0.473 \\
(-0.921 ; 0.515)\end{array}$ & $\begin{array}{l}-0.146 \\
(-0.409 ; 0.134)\end{array}$ \\
\hline Shrubs & 13 & 3 & $\begin{array}{l}-0.111 * \\
(-0.166 ;-0.054)\end{array}$ & $89.5 \%$ & $\begin{array}{l}-0.132 \\
(-0.336 ; 0.084)\end{array}$ & - & $\begin{array}{l}-0.079 \\
(-0.174 ; 0.017)\end{array}$ & - \\
\hline $\begin{array}{l}\text { Wetland woody veg. (non- } \\
\text { specific) }\end{array}$ & 11 & 3 & $\begin{array}{l}-0.302 \\
(-0.727 ; 0.29)\end{array}$ & $96.9 \%$ & - & - & - & - \\
\hline
\end{tabular}


20 Table A4. Prairie region. Summary effect sizes for the relationships of habitat to secretive marsh birds in the Prairie region.

21 Asterisks indicate statistically significant mean effect sizes (95\% confidence intervals did not overlap 0). Values are not reported when

22 there were $<3$ studies for a variable and species. Species codes are AMBI $=$ American Bittern, LEBI $=$ Least Bittern, SORA $=$ Sora,

23 VIRA = Virginia Rail. $I^{2}$ indicates the percent of variability in mean effect size estimates of a habitat variable that is due to

24 heterogeneity rather than sampling error.

\begin{tabular}{|c|c|c|c|c|c|c|c|c|}
\hline \multirow[b]{2}{*}{ Habitat variable } & \multicolumn{2}{|l|}{ Number of } & \multirow[b]{2}{*}{ Mean effect size } & \multirow[b]{2}{*}{$\mathrm{I}^{2}$} & \multicolumn{4}{|c|}{ Mean effect size for species } \\
\hline & Effect sizes & Studies & & & AMBI & LEBI & SORA & VIRA \\
\hline $\begin{array}{l}\text { Agriculture } \\
\text { (percent cover) }\end{array}$ & 31 & 5 & $\begin{array}{l}-0.023 \\
(-0.078 ; 0.031)\end{array}$ & $89.7 \%$ & $\begin{array}{l}-0.17^{*} \\
(-0.225 ;-0.113)\end{array}$ & - & $\begin{array}{l}0.122 * \\
(0.055 ; 0.188)\end{array}$ & $\begin{array}{l}0.0004 \\
(-0.093 ; 0.094)\end{array}$ \\
\hline $\begin{array}{l}\text { Forest } \\
\text { (percent cover) }\end{array}$ & 1 & 1 & - & - & - & - & - & - \\
\hline $\begin{array}{l}\text { Wetland } \\
\text { (percent cover) }\end{array}$ & 50 & 7 & $\begin{array}{l}0.055^{*} \\
(0.029 ; 0.08)\end{array}$ & $61.9 \%$ & $\begin{array}{l}0.076^{*} \\
(0.013 ; 0.139)\end{array}$ & - & $\begin{array}{l}0.077 * \\
(0.044 ; 0.110)\end{array}$ & $\begin{array}{l}0.036 \\
(-0.007 ; 0.079)\end{array}$ \\
\hline $\begin{array}{l}\text { Urban } \\
\text { (percent cover) }\end{array}$ & 18 & 2 & - & - & - & - & - & - \\
\hline $\begin{array}{l}\text { Open water } \\
\text { (percent cover) }\end{array}$ & 26 & 4 & $\begin{array}{l}-0.069 * \\
(-0.118 ;-0.019)\end{array}$ & $93.6 \%$ & $\begin{array}{l}0.007 \\
(-0.031 ; 0.044)\end{array}$ & - & - & $\begin{array}{l}-0.063 \\
(-0.196 ; 0.072)\end{array}$ \\
\hline Wetland size & 3 & 2 & - & - & - & - & - & - \\
\hline Interspersion & 5 & 1 & - & - & - & - & - & - \\
\hline Water depth & 4 & 2 & - & - & - & - & - & - \\
\hline Vegetation height & 4 & 2 & - & - & - & - & - & - \\
\hline $\begin{array}{l}\text { Non-woody emergent veg. } \\
\text { (percent cover) }\end{array}$ & 17 & 4 & $\begin{array}{l}0.219^{*} \\
(0.01 ; 0.41)\end{array}$ & $95.9 \%$ & - & - & - & - \\
\hline Robust emergent veg. & 9 & 4 & $\begin{array}{l}0.339 \\
(-0.061 ; 0.645)\end{array}$ & $97.5 \%$ & - & - & - & - \\
\hline Typha & 9 & 4 & $\begin{array}{l}0.339 \\
(-0.061 ; 0.645)\end{array}$ & $97.5 \%$ & & & & \\
\hline Non-robust emergent veg. & 4 & 2 & - & - & - & - & - & - \\
\hline Emergent veg. (non-specific) & 0 & 0 & - & - & - & - & - & - \\
\hline $\begin{array}{l}\text { Wetland woody veg. } \\
\text { (percent cover) }\end{array}$ & 6 & 3 & $\begin{array}{l}0.008 \\
(-0.057 ; 0.073)\end{array}$ & $0 \%$ & - & - & - & - \\
\hline Shrubs & 2 & 1 & - & - & - & - & - & - \\
\hline $\begin{array}{l}\text { Wetland woody veg. } \\
\text { (non-specific) }\end{array}$ & 2 & 1 & - & - & - & - & - & - \\
\hline
\end{tabular}


26 Table A5. Riparian region. Summary effect sizes for the relationships of habitat to secretive marsh birds in the Great Lakes region.

27 Asterisks indicate statistically significant mean effect sizes (95\% confidence intervals did not overlap 0). Values are not reported when

28 there were $<3$ studies for a variable or species. Species codes are AMBI $=$ American Bittern, LEBI $=$ Least Bittern, SORA $=$ Sora,

29 VIRA = Virginia Rail. $I^{2}$ indicates the percent of variability in mean effect size estimates of a habitat variable that is due to

30 heterogeneity rather than sampling error.

\begin{tabular}{|c|c|c|c|c|c|c|c|c|}
\hline \multirow[b]{2}{*}{ Habitat variable } & \multicolumn{2}{|l|}{ Number of } & \multirow[b]{2}{*}{ Mean effect size } & \multirow[b]{2}{*}{$I^{2}$} & \multicolumn{4}{|c|}{ Mean effect size for species } \\
\hline & Effect sizes & Studies & & & AMBI & LEBI & SORA & VIRA \\
\hline $\begin{array}{l}\text { Agriculture } \\
\text { (percent cover) }\end{array}$ & 3 & 1 & - & - & - & - & - & - \\
\hline $\begin{array}{l}\text { Forest } \\
\text { (percent cover) }\end{array}$ & 1 & 1 & - & - & - & - & - & - \\
\hline $\begin{array}{l}\text { Wetland } \\
\text { (percent cover) }\end{array}$ & 2 & 2 & - & - & - & - & - & - \\
\hline $\begin{array}{l}\text { Urban } \\
\text { (percent cover) }\end{array}$ & 0 & 0 & - & - & - & - & - & - \\
\hline $\begin{array}{l}\text { Open water } \\
\text { (percent cover) }\end{array}$ & 8 & 6 & $\begin{array}{l}0.021 \\
(-0.158 ; 0.199)\end{array}$ & $66.6 \%$ & - & $\begin{array}{l}-0.031 \\
(-0.259 ; 0.199)\end{array}$ & - & - \\
\hline Wetland size & 0 & 0 & - & - & - & - & - & - \\
\hline Interspersion & 7 & 4 & $\begin{array}{l}0.172 \\
(-0.002 ; 0.336)\end{array}$ & $75.5 \%$ & - & - & - & - \\
\hline Water depth & 9 & 5 & $\begin{array}{l}0.063 \\
(-0.097 ; 0.219)\end{array}$ & $96.7 \%$ & - & - & $\begin{array}{l}0.174 \\
(-0.424 ; 0.666)\end{array}$ & - \\
\hline Vegetation height & 7 & 3 & $\begin{array}{l}0.167 \\
(-0.12 ; 0.428)\end{array}$ & $92.0 \%$ & - & - & - & - \\
\hline $\begin{array}{l}\text { Non-woody emergent veg. (percent } \\
\text { cover) }\end{array}$ & 66 & 13 & $\begin{array}{l}0.056^{*} \\
(0.013 ; 0.098)\end{array}$ & & & $\begin{array}{l}0.036 \\
(-0.086 ; 0.157)\end{array}$ & $\begin{array}{l}0.084^{*} \\
(0.003 ; 0.165)\end{array}$ & \\
\hline Robust emergent veg. & 14 & 4 & $\begin{array}{l}0.14 * \\
(0.036 ; 0.241)\end{array}$ & $57.7 \%$ & - & $\begin{array}{l}0.243 \\
(-0.111 ; 0.542)\end{array}$ & & \\
\hline Typha & 11 & 2 & - & - & - & - & - & - \\
\hline Non-robust emergent veg. & 38 & 5 & $\begin{array}{l}0.002 \\
(-0.048 ; 0.052)\end{array}$ & $85.7 \%$ & - & - & $\begin{array}{l}0.058 \\
(-0.045 ; 0.159)\end{array}$ & - \\
\hline Emergent veg. (non-specific) & 5 & 4 & $\begin{array}{l}0.153 \\
(-0.144 ; 0.425)\end{array}$ & $63.9 \%$ & - & $\begin{array}{l}0.098 \\
(-0.182 ; 0.363)\end{array}$ & - & - \\
\hline $\begin{array}{l}\text { Wetland woody veg. } \\
\text { (percent cover) }\end{array}$ & 38 & 8 & $\begin{array}{l}-0.075^{*} \\
(-0.127 ;-0.022)\end{array}$ & $57.5 \%$ & - & $\begin{array}{l}-0.05 \\
(-0.104 ; 0.003)\end{array}$ & $\begin{array}{l}-0.211 * \\
(-0.353 ;-0.061)\end{array}$ & - \\
\hline Shrubs & 1 & 1 & - & - & - & - & - & - \\
\hline Wetland woody veg. & 14 & 5 & $\begin{array}{l}-0.064 \\
(-0.144 ; 0.017)\end{array}$ & $49.9 \%$ & - & $\begin{array}{l}-0.085 \\
(-0.218 ; 0.051)\end{array}$ & - & - \\
\hline
\end{tabular}


32 Figure A1. Mean effect sizes (Fisher's z) representing the association of secretive marsh birds 33 with 17 habitat variables based on meta-analysis of studies conducted within three regions 34 (Riparian, Prairie, and Great Lakes) in the Mississippi Flyway. Lines around the mean represent $3595 \%$ confidence intervals.

36

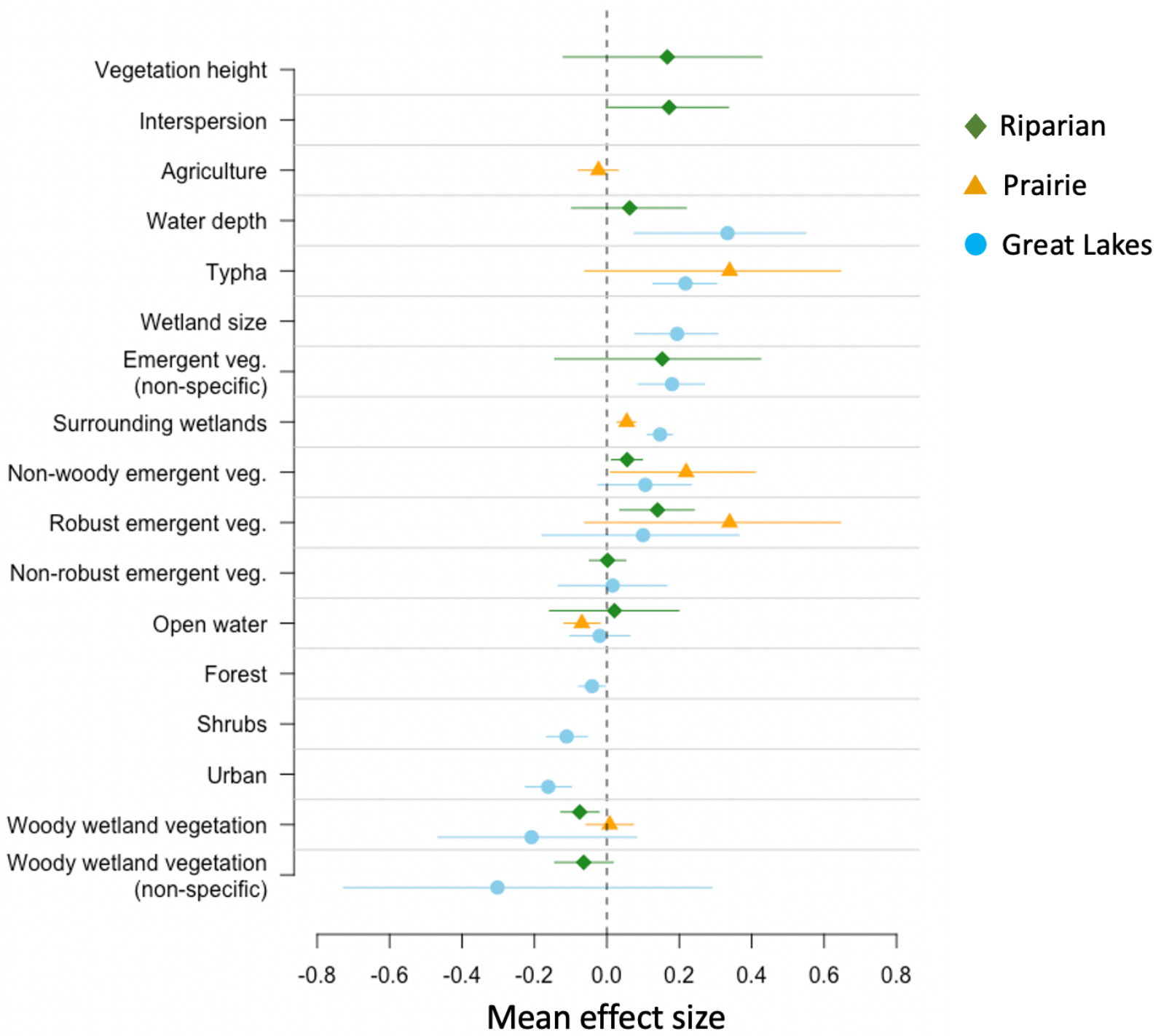


Reference A1. Bibliography of studies used in the meta-analysis on secretive marsh bird habitat associations in the Mississippi Flyway.

Arnold, K. E. 2005. The breeding ecology of least bitterns (Ixobrychus exilis) at Agassiz and Mingo National Wildlife Refuges. South Dakota State University.

Austin, J. E., and D. A. Buhl. 2013. Relating yellow rail (Coturnicops noveboracensis) occupancy to habitat and landscape features in the context of fire. Waterbirds 36:199-213.

Blake-Bradshaw, A. G. 2018. Wetland suitability for waterbirds in Illinois. Thesis, University of Illinois.

Bolenbaugh, J. R., T. Cooper, R. S. Brady, K. L. Willard, and D. G. Krementz. 2012. Population status and habitat associations of the king rail in the Midwestern United States. Waterbirds 35:535-545.

Bolenbaugh, J. R., D. G. Krementz, and S. E. Lehnen. 2011. Secretive marsh bird species co-occurrences and habitat associations across the Midwest, USA. Journal of Fish and Wildlife Management 2:49-60.

Bookhout, T. A., and J. R. Stenzel. 1987. Habitat and movements of breeding yellow rails. Wilson Bulletin 99:441-447.

Brittain, R., and J. Thieme. 2011. Coordinated Bird Monitoring on Indiana Important Bird Areas. National Audubon Society.

Budd, M. J., and D. G. Krementz. 2010. Habitat use by Least Bitterns in the Arkansas Delta. Waterbirds 33:140-147.

Chandler, R. C., and R. A. Weiss. 1995. Status and distribution of marsh-nesting birds in northern Indiana. Indiana DNR.

Clark-Schubert, N. D. 2009. Fall migration ecology of the Sora (Porzana carolina) at Four Rivers Conservation Area in Missouri. Thesis, University of Arkansas. $<$ https://search.proquest.com/docview/304828128/abstract/BAEC8B9854AB46 7BPQ/19>.

Darrah, A. J., and D. G. Krementz. 2009. Distribution and Habitat Use of King Rails in the Illinois and Upper Mississippi River Valleys. The Journal of Wildlife Management 73:1380-1386.

Darrah, A. J., and D. G. Krementz. 2010. Occupancy and habitat use of the Least Bittern and Pied-billed Grebe in the Illinois and Upper Mississippi River Valleys. Waterbirds 33:367-375.

Darrah, A. J., and D. G. Krementz. 2011. Habitat use of nesting and brood-rearing King Rails in the Illinois and Upper Mississippi River Valleys. Waterbirds 34:160-167.

Fournier, A. M. V. 2017. Phenology, Habitat Use, and the Impacts of Wetland Management on Autumn Migrating Rails in Missouri. PhD Dissertation, University of Arkansas. $<$ https://search.proquest.com/docview/1879756773/abstract/BAEC8B9854AB4 $67 \mathrm{BPQ} / 12>$

Fournier, A. M., D. C. Mengel, and D. G. Krementz. 2017. Virginia and Yellow Rail autumn migration ecology: synthesis using multiple data sets. Animal Migration 4:15-22. 
Glisson, W. J., R. S. Brady, A. T. Paulios, S. K. Jacobi, and D. J. Larkin. 2015.

Sensitivity of secretive marsh birds to vegetation condition in natural and restored wetlands in Wisconsin. The Journal of Wildlife Management 79:11011116.

Hansen, J. M. 2019. Survey Methods and Habitat Associations of Secretive Marsh Birds in Coastal Wetlands of the Western Lake Erie Basin. PhD Dissertation, The Ohio State University.

Harms, T. M., and S. J. Dinsmore. 2013. Habitat associations of secretive marsh birds in Iowa. Wetlands 33:561-571.

Harms, T. M., K. T. Murphy, X. Lyu, S. S. Patterson, K. E. Kinkead, S. J. Dinsmore, and P. W. Frese. 2017. Using landscape habitat associations to prioritize areas of conservation action for terrestrial birds. PloS one 12.

Hay, S., and M. Manseau. 2007. Distribution and nesting habitat of least bitterns and other marsh birds in Manitoba. Proceedings of the Species at Risk 2004 Pathways to Recovery Conference.

Hill, E. B. 2015. Linking wetland management decisions to secretive marsh bird habitat use during spring migration and summer breeding on public wetlands in Missouri. Thesis, University of Missouri - Columbia.

Johnson, R. R. 1984. Breeding habitat use and postbreeding movements by Soras and Virginia Rails. Thesis, Iowa State University

Johnson, R. R., and J. J. Dinsmore. 1986. Habitat use by breeding Virginia rails and soras. The Journal of Wildlife Management 50:387-392.

Kahler, B. M. 2013. Area-sensitivity, landscape habitat associations and distribution of breeding marsh birds within the glaciated region of Ohio, USA. PhD Dissertation, The Ohio State University.

Kirk, D. A., M. Csizy, R. C. Weeber, C. M. Francis, and J. D. McCracken. 2001. Habitat associations of marsh-nesting birds in the Great Lakes Basin: implications for local conservation and management. Report, Wildlife Habitat Canada.

Lor, S. K. 2007. Habitat use and home range of American bitterns (Botaurus lentiginosus) and monitoring of inconspicuous marsh birds in northwest Minnesota. PhD Dissertation, University of Missouri - Columbia. $<$ https://search.proquest.com/docview/304840252/abstract/BAEC8B9854AB46 $7 \mathrm{BPQ} / 10>$.

Martin, K. A. 2012. Habitat Suitability of the Yellow Rail in South-Central Manitoba. Thesis, University of Manitoba. $<$ https://search.proquest.com/docview/1506938081/abstract/BAEC8B9854AB4 $67 \mathrm{BPQ} / 15>$

Monfils, M. J., and R. G. Corace. 2018. Marsh bird response to hydrologic alteration and restoration of wetlands in the boreal hardwood transition. Michigan Natural Features Inventory, Report Number 2018-08, Lansing, USA.

Moore, S. B. 2000. Least bittern habitat selection and breeding productivity in southern Illinois mined land wetlands. Thesis, Southern Illinois University at Carbondale. 
Mushanski, M. D. 2015. Habitat Selection by Birds in Willow-Ringed Wetlands: Management Implications for Harvesting Willow Biomass. Thesis, University of Regina.

Prairie Habitat Joint Venture. 2014. Prairie Habitat Joint Venture Implementation Plan 2013-2020: The Prairie Parklands. Report of the Prairie Habitat Joint Venture, Environment Canada. $<$ https://www.phjv.ca/wpcontent/uploads/2017/10/PHJV-Implemenetation-Plan-PRAIRIEPARKLAND-2013-2020-Final.pdf $>$

Reid, F. A. 1989. Differential habitat use by waterbirds in a managed wetland complex. PhD Dissertation, University of Missouri - Columbia. $<\underline{\text { https://search.proquest.com/docview/303718082/abstract/BAEC8B9854AB46 }}$ $7 \mathrm{BPQ} / 8>$

Saunders, S. P., K. A. L. Hall, N. Hill, and N. L. Michel. 2019. Multiscale effects of wetland availability and matrix composition on wetland breeding birds in Minnesota, USA. The Condor 121:1-15.

Scott, L. A. 2010. Species richness and habitat use of secretive marsh birds in managed wetlands in the Arkansas River Valley of western Arkansas. Thesis, University of Arkansas. $<$ https://search.proquest.com/docview/822142093/abstract/BAEC8B9854AB46 7BPQ/6>

Smith-Cartwright, L., and L. Chow-Fraser. 2012 Landscape-scale influences on Least Bittern (Ixobrychus exilis) habitat use in southern Ontario coastal marshes. Unpublished manuscript. $<$ https://greatlakeswetlands.ca/wp-content/uploads/2012/09/Least-BitternManuscript.pdf> Accessed on February 6, 2020.

Tozer, D. C. 2016. Marsh bird occupancy dynamics, trends, and conservation in the southern Great Lakes basin: 1996 to 2013. Journal of Great Lakes Research 42:136-145.

Tozer, D. C., E. Nol, and K. F. Abraham. 2010. Effects of local and landscape-scale habitat variables on abundance and reproductive success of wetland birds. Wetlands Ecology and Management 18:679-693.

Tozer, D. C., R. L. M. Stewart, O. Steele, and M. Gloutney. 2020. Species-Habitat Relationships and Priority Areas for Marsh-Breeding Birds in Ontario. The Journal of Wildlife Management 84:786-801.

Valente, J. J., S. L. King, and R. R. Wilson. 2011. Distribution and habitat associations of breeding secretive marsh birds in Louisiana's Mississippi Alluvial Valley. Wetlands 31:1-10.

Winstead, N. A., and S. L. King. 2006. Least Bittern distribution among structurally different vegetation types in managed wetlands of northwest Tennessee, USA. Wetlands 26:619. 